\title{
Pembaharuan Pemikiran Muhammad Arkoun
}

\author{
Oleh: FidiaArdana dan Meta Ratna Sari \\ UIN Sultan Syarif Kasim Riau
}

\begin{abstract}
Abstrak: Muhammad Arkoun sebagai salah satu tokoh di antara banyaknya pemikir dan tokoh muslim yang memberikan tawaran dalam metodologi penafsiran Al-Qur'an. Teori-teori yang muncul dalam hal penafsiran Al-Qur'an pun juga sangat kaya. Muhammed Arkoun menawarkan kajian yang cukup menggingit dan berani dalam pembacaannya terhadap al-Qur'an. Secara radikal Arkoun mempersoalkan kembali esensi wahyu sebagai kalam Allah yang transenden dan wacana wahyu sebagai perwujudan kalam tersebut dalam dataran imanen. Ia menekankan pembacaan al-Qur'an sebagai kajain yang memungkinkan suatu pembacaan yang ideal bertepatan dengan maksud-maksud pemaknaan yang asli dari al-Qur'an pada tahap wacana bukan pada tahap teks. Dengan mengadopsi ilmu-ilmu barat kontemporer dalam menafsirkan Al-Qur'an, baik itu ilmu linguistik, sejarah, antropologi dan yang lainnya, dia mengharapkan akan menghasilkan penafsiran baru yang belum pernah dilakukan oleh ilmuan muslim sebelumnya. Ia telah mengangkat hermeneutika al-Qur'an dalam terma-terma kontemporer modern sehingga penafsiran al-Qur'an yang ia tawarkan cukup menggeser peran metode tafsir alQur'an bil ma'tsur .
\end{abstract}

Kata kunci: Arkoun, Wahyu, al-Quran, Tafsir.

\section{A. Pendahuluan}

Arkoun, Muhammed (1. 1928) adalah seorang sarjana Islam dan Penulis Aljazair. Sabagai salah seorang intelektual Muslim Arab terkemuka dewasa ini, Arkoun terlibat dalam tugas yang sangat penting untuk menafsirkan dan menyusun kembali tradisi-tradisi keagamaan, fiqih, dan filosofis klasik melalui sistem hermeneutik ${ }^{1}$

\footnotetext{
${ }^{1}$ Hermeneutika secara umum dapat didefinisikan sebagai suatu teori atau filsafat tentang interpretasi makna. Secara etimologis, kata hermeneutik berasal dari bahasa Yunani hermeneuin yang berarti menafsirkan. Maka kata benda hermeneia secara harfiah dapat diartikan penafsiran atau interpretasi. Istilah tersebut dalam berbagai bentuknya dapat dibaca dalam sejumlah literatur peninggalan yunani kuno, seperti digunakan Aristoteles dalam sebuah risalah yang berjudul Peri Hermeneias (tentang penafsiran). Kata itu kemudian diserap ke dalam bahasa Jerman yaitu hermeneutik dan hermeneutics dalam bahasa Inggris.
} 
canggih yang terilhami oleh metodoligi kritis barat kontemporer-tugas yang membuatnya menjadi seorang pemikir kontroversial dalam menciptakan wacana kritis arab-islam modern. ${ }^{2}$

Sebagai seorang guru besar pemikiran Islam di Sorboun University, Perancis, pikiran-pikirannya banyak dipengaruhi oleh filosof-filosof Perancis seperti Michael Foucault, Jacques Derrida, terutama tentang teori dekonstruksinya ${ }^{3}$. Kritik yang ditawarkan oleh Arkoun adalah kritik nalar pemikiran Islam yang masih didominasi oleh nalar Arab. Kritik ini tidak hanya berpijak kepada penyelidikan pengetahuan dan pemikiran atau sekedar meruntuhkan tesa, konsep, atau mazhab, tetapi lebih dari itu bagaimana menyelidiki sistem pengetahuan, menyelidiki dasar-dasar pemikiran dan mekanismenya serta melihat bagaimana cara memproduksi makna dan kaidah yang membentuk wacana. Dari sinilah kemudian Arkoun melampaui tingkat epistemologi ${ }^{4}$ tradisional, dan sudah menyentuh pada wilayah arkeologi pemikiran Islam. Pada level ini, warisan pemikiran Islam dibongkar dan selanjutnya menggali lapisan-lapisannya untuk menyingkap makna yang mendalam dalam pemikiran Islam. ${ }^{5}$

Keberanian Arkoun tersebut didorong oleh kegelisahannya terhadap mereka yang dikatakan sebagai kalangan ortodok yang ia lihat telah melakukan penyalahgunaan al-Qur'an untuk kepentingan mereka baik idiologis mapun politis. Arkoun menengarai

Dalam terminologi modern, hermeneutika juga merupakan ilmu yang digunakan dalam mencari pemahaman teks secara umum, yaitu dengan memunculkan pertanyaan-pertanyaan yang beragam dan saling berkaitan seputar teks dari segi karakteristiknya dan hubungannya dengan kondisi yang melingkupinya dari satu sisi serta hubungannya dengan pengarang teks serta pembacanya dari sisi yang lain. Selain itu, penting dicatat bahwa hermeneutika fokus membahas dengan serius seputar hubungan penafsir (atau kritikus teks sastrawi) dengan teks khususnya yang berkaitan dengan Alkitab. Tujuan dari hermeneutika adalah untuk menemukan kebenaran dan nilai-nilai dalam Bible. Lihat: M. Ilham Muchtar, Analisis Konsep Hermeneutika dalam Tafsir al-Quran, Hunafa: Jurnal Studia Islamika, Vol. 13, No. 1 Juni 2016, 69.

2 John. L.Esposito, Ensiklopedi Oxford Dunia Islam Modern,

(T.tp.: Meizan, t.t.), 174

${ }^{3}$ https://id.m.wikipedia.org.

${ }^{4}$ Epistemologi merupakan cabang filsafat ilmu yang berbicara tentang metode untuk memperoleh dan menyusun struktur bangunan ilmu, atau struktur nalar yang membentuk ilmu. Lihat : foot note 1 dalam Irwan Malik Marpaung, Kritik terhadap 'Kritik Nalar Islam' Arkoun, Inpasonline.com, 12 of 14.

${ }^{5}$ Muhaemin Latif, Membumikan Teologi Islam dalam Kehidupan Modern (Berkaca dari Mohammed Arkoun), Jurnal Dakwah Tabligh, Vol. 14, No. 2, 2013, 171. 
penyalahgunaan tersebut diakibatkan oleh ketidakmampuan mereka untuk mengungkap secara jernih pesan al-Qur'an sebagai man ia diturunkan dalam sebuah situasi sosial yang hidup. Dia banyak mengadopsi ilmu-ilmu barat kontemporer dalam menafsirkan AlQur'an, baik itu ilmu linguistik, sejarah, antropologi dan yang lainnya. Dengan demikian dia mengharapkan akan menghasilkan penafsiran baru yang belum pernah dilakukan oleh ilmuan muslim sebelumnya. Muhammad Arkoun termasuk intelektual muslim yang telah mengangkat hermeneutika al-Qur'an dalam terma-terma kontemporer modern dan juga merupakan salah seorang pemikir muslim yang berpengaruh. ${ }^{6}$

Pemikiran dan karya-karya Arkoun sangat ketara dipegaruhi oleh gerakan (post) strukturalitis Perancis. Metode historisme yang dipakai Arkoun adalah formulasi ilmu-ilmu social barat modern hasil ciptaan para pemikir (post) strukturalis Perancis_referensi utamanya adalah De Sausure ${ }^{7}$ (linguistik), Levi Staurus ${ }^{8}$ (antropologi), Lacan ${ }^{9}$ (psokologi), Barthes ${ }^{10}$ (smiologi), Foucault (epistimologi), Derrida ${ }^{11}$

\footnotetext{
${ }^{6}$ Nasrudin, Manhaj Tafsir Muhammad Arkoun, Jurnal Maghza Vol. 1, No. 1, Januari-Juni 2016, 86.

${ }^{7}$ De Saussure membuat perbedaan antara bahasa sebagai sistem (langue) dan bahasa sebagai wicara (parole). Wicara bersifat individual dan intensional, sedangkan bahasa bersifat kolektif dan anonim. Lihat: Siti Rohmah Soekarba, Kritik Pemikiran Arab: Metode Dekonstruksi Mohammen Arkoun, Wacana, Vol 8, No l, APRIL 2006, 80 .

${ }^{8}$ Levi Stauss yang memiliki spesifikasi dalam menyingkap mitologi yang dibentok oleh budaya, masyarakat tertentu dimana segala bentukan budaya sebetulnya tidak akan lepas dari tarik-ulur masa lalu. Ia mendeteksi bahwa bahasa merupakan jalan menuju cakrawala pembacaan baru dan sebagai acuan analisa antropologi suatu masyarakat dan (bahkan) segala bentuk ciptaan masyarakat. Lihat: Irwan Malik Marpaung, Kritik terhadap 'Kritik Nalar Islam' Arkoun, Inpasonline.com, 21
} September 2010, 22:11, 1 of 14 .

${ }^{9}$ Jaques Lacan adalah seorang pemikir Prancis yang mempelajari psokologi Sigmund Frued. Ia mampu mengkomparisakan psikologi dengan analisa kebahasaan dan karenanya menganggap bahwa psiko-analisis sebanding lurus dengan strukturalis. Lihat: foot note ke 12 dalam : Irwan Malik Marpaung, Kritik terhadap 'Kritik Nalar Islam' Arkoun, Inpasonline.com, 21 September 2010, 22:11, 13 of 14.

${ }^{10}$ Barthes mengikuti jejak Saussure dalam semiologi. Arkoun mengembangkan pendekatan mitos Barthes dan Ricoeur pada Alquran dan agama Islam. Ia meminjam ungkapan Ricoeur untuk melakukan semacam re-enactment pengalaman keagamaan pada analisis antropologis (mitis atau simbolis) ketika membaca Surat al-Fâtihah. Lihat: Siti Rohmah Soekarba, Kritik Pemikiran Arab: Metode Dekonstruksi Mohammen Arkoun, Wacana, Vol 8, No l, APRIL 2006, 81.

${ }^{11}$ Derrida mengetengahkan proses kritik dari dalam yang disebutnya "dekonstruksi" atau "pembongkaran". Proses pembongkaran yang mendapat 
(grammatologi) filosof Perancis Paul Ricour ${ }^{12}$, antropolog seperti Jack Goody dan Pierre Bourdieu. ${ }^{13}$

Apa yang diinginkan oleh Arkoun sebenarnya adalah bagaimana menghadirkan wahyu dalam konteks sejarah. Dengan kata lain, ia ingin membumikan teologi Islam dalam kerangka kekinian yang terkait dengan kehidupan modern. Warisan pemikiran Islam bukanlah sesuatu yang ahistoris. Ia berkait kelindan dengan realitas yang mengitarinya. Arkoun mengatakan bahwa "kita harus mengetahui bahwa al-Qur'an adalah wacana yang mengakar dalam sebuah sejarah yang dinamis dan dapat dirasakan". Artinya bahwa ia terangkai dalam sejarah keseharian dan kebiasaan yang lebih besar. Hanya saja, realitasnya menggambarkan bagaimana aspek kesejarahannya menjadi terhalang dan berubah menjadi "sesuatu yang suci dan transenden". Dengan kata lain, pemikiran teologi Islam lebih sebagai dogma yang tidak perlu disentuh apalagi dibongkar karena ia seakan-akan berada di luar sejarah. ${ }^{14}$

Untuk dapat menangkap aspek kesejarahan wacana qurani diatas, maka menurut Arkoun, kita tidak boleh menutup mata terhadap metode dan pendekatan Barat dalam memahami sesuatu, seperti ilmu bahasa (linguistik), humaniora, sejarah, sosiologi, bahkan epistemologi, arkeologi serta geneologi. Ilmu-ilmu ini penting untuk diketahui agar makna yang terbangun pada awal munculnya warisan Islam dapat terungkap. Sisi inilah yang membuat pikiran Arkoun menjadi menarik untuk ditelaah lebih jauh disamping keunikannya

perhatian khusus Derrida adalah "yang tak dipikirkan" dan "yang tak terpikir". Lihat: Siti Rohmah Soekarba, Kritik Pemikiran Arab: Metode Dekonstruksi Mohammen Arkoun, Wacana, Vol 8, No 1, APRIL 2006, 81.

${ }^{12}$ Ricoeur merumuskan mitos sebagai simbol sekunder yang membicarakan kenyataan manusia. Oleh karena itu, mitos bukanlah sesuatu yang harus ditinggalkan demi memodernkan pemikiran manusia. Yang harus ditinggalkan adalah penyalahgunaan mitos. Arkoun mengambil alih teori itu. Menurutnya, seperti juga berbagai kisah dalam Alkitab, wacana Alquran bersusunan mitis. Dalam keadaan sosial-historis, wacana Alquran berubah menjadi korpus tertutup. Lihat: Siti Rohmah Soekarba, Kritik Pemikiran Arab: Metode Dekonstruksi Mohammen Arkoun, Wacana, Vol 8, No 1, APRIL 2006, 82.

${ }^{13}$ Arkoun, telah Tiada dan Telaan Kritis Pemikirannya, Inpasonline,20/09/10, 20 September 2010, 23:5l.

${ }^{14}$ Muhaemin Latif, Membumikan Teeologi Islam dalam Kehidupan Modern (Berkaca dari Mohammed Arkoun), 171. 
tetapi juga keberaniannya untuk menyentuh sesuatu yang telah disakralkan pada pergulatan pemikiran teologi Islam. ${ }^{15}$

Sebagai seorang pemikir pascamodernis, Arkoun memiliki pandangan-pandangan yang sangat sulit dicerna, apalagi epistemologinya. Untuk memahami pemikirannya secara menyeluruh, kita perlu mendalami ilmu pengetahuan mutakhir yang berkembang terutama di Prancis, seperti linguistik, antropologi, semiotika, serta perbagai gagasan dan pendekatan wacana pascamodernis yang sangat diakrabi oleh Arkoun. Arkoun menggunakan bahasa yang rumit dalam karyanya. Seperti dikemukakannya sendiri, hampir mustahil mengungkapkan gagasan dalam bahasa bangsa yang belum memikirkannya. Dalam hal ini, Arkoun mengikuti tradisi Prancis tertentu. Salah satu aspek dari kesulitan bahasa Arkoun adalah kecenderungannya menggunakan aneka istilah dan ungkapan tanpa rumusan yang jelas atau dalam berbagai arti yang berbeda. Hal itu antara lain disebabkan banyaknya sumber rujukan yang digunakan secara variatif. ${ }^{16}$

\section{B. Biografi Muhammad Arkoun}

\section{Kelahiran Arkoun}

Muhammad Arkaoun lahir pada 1 Februari $1928^{17}$ di TourirtMimoun, Kabyliah ${ }^{18}$, Aljazair. Kabila merpakan daerah pegunungan berpenduduk Berber, terletak disebelah timur Aljir. Berber adalah penduduk yang tersebar di Afrika bagian utara. Bahasa yang dipakai adalah bahasa non-Arab ('ajamiyah). ${ }^{19}$

\footnotetext{
${ }^{15}$ Muhaemin Latif, Membumikan Teeologi Islam dalam Kehidupan Modern (Berkaca dari Mohammed Arkoun), 171.

${ }^{16}$ Siti Rohmah Soekarba, Kritik Pemikiran Arab: Metode Dekonstruksi Mohammen Arkoun, Wacana, Vol 8, No. 1, April 2006, 89.

172 Januari 1928, Lihat Moh.Fauzan dan Muhammad Alfan, Dialog Pemikiran Timur Barat, (Bandung: Pustaka Setia, 2011), 214., 28 Februari 1928, Lihat Baedhowi, Humanisme Islam: Kajian Terhadap Pemikiran Filosofis Muhammad Arkoun, (Yogyakarta: Pustaka Pelajar, 2008), 25.

${ }^{18}$ Daerah Kabilia ini secara geografis terbagi menjadi dua bagian yang terbentang di sepanjang pegunungan Jurjuran (dengan ketinggian sekitar 2.705 m/7.565 kaki dan luas kurang lebih satu juta hektar). Daerah ini terdiri dari l). Kabilia Besar dibagian utara dengan ibukota daerahnya Tizi-Uzu dan 2). Kabilia Kecil di bagian sebelah selatan dan timur. Lihat Baedhowi, Humanisme Islam: Kajian Terhadap Pemikiran Filosofis Muhammad Arkoun, (Yogyakarta: Pustaka Pelajar, 2008), 25.

${ }^{19}$ Hermeneutika Muhamed Arkoun: Sekedar Pengantar, (T.tp.:T.pn., 2009) 10 of 10
} 
Secara historis Aljazair terislamkan karena ditaklukkan oleh bansa Arab dibawah komando'Uqbah bin Nafi' pada 683 M. Mayoritas bangsa Berber memeluk Islam bersama 'uqbah. Adapun corak keislaman yang berkembang pada masyarakat Berber dan sebagian besar masyarakat Afrika Utara adalah model sufisme. ${ }^{20}$

\section{Keluarga Arkoun}

orang tua Arkoun adalah tokoh masyarakat di daerahnya dan masih menggunakan bahasa aslinya, Kabilia. Walaupun demikian Arkoun sendiri menguasai dengan baik bahasa Arab, bahasa nasional Aljazair yang ia pelajari sejak muda. Tetapi dalam mengungkapkan gagasannya ia banyak menulis dalam bahasa Prancis. ${ }^{21}$

Sebagai anak seorang pedagang rempah-rempah, Arkoun tumbuh menjadi sarjana dan pemikir internasional yang sangat sukses. ${ }^{22}$ Arkoun berasal dari keluarga sederhana yang tergolong pada strata sosial yang rendah. Dalam masyarakat Kabyliah, islam berkembang melalui tradisi lisan sehingga taktek hafalan komunal cenderung mengabaikan study literet. Ketika Arkoun lahir dan dibesarkan, Aljazair berada dibawah kekuasaan Prancis. Prancis melakukan kolonisasi dan menguasai Negara itu sejak $1830 .{ }^{23}$

\section{Pendidikan Arkoun}

Pendidikan dasar Arkoun dimulai dari desa asalnya Kabilia. ${ }^{24}$ dan kemudian melanjutkan sekolah menengah di kota pelabuhan Oran, sebuh kota utama di Aljazair bagian barat yang jauh dari Kabilia. kemudian Arkoun melanjutkan studi bahasa dan sastra di Universitas Aljir(1950-1954), sambil mengajar bahasa Arab pada sebuah sekolah menengah atas di Al-Harach yang berlokasi didaerah pinggiran ibu kota Aljazair.

Pada saat perang kemerdekaan Aljazair dari Prancis (1954=1962). Arkoun melanjutkan studi tentang bahasa dan sastra Arab di Universitas Sorbonne, paris. Ketika itu, dia sempat bekerja sebagai agrege bahasa dan kesusastraan Arab di Paris serta mengajar SMA (Lyce) di Strasbourg (daerah Prancis sebelah timur laut) dan

\footnotetext{
${ }^{20}$ Baedhowi, Humanisme Islam, Op.cit, 27.

${ }^{21}$ Baedhowi, Humanisme Islam, 27.

${ }^{22}$ John. L.Esposito, Ensiklopedi Oxford Dunia Islam Modern, (T.tp.: Meizan, t.t.), 174

${ }^{23}$ Ahmad Munir, "Kritik Nalar Islam: Analisis atas Pemikiran Muhammad Arkaoun," Al-Tahrir Jurnal Pemikiran Islam Volt.8, no.2l-40 (Januari: 2008): 23.

${ }^{24}$ Ahmad Munir, "Kritik Nalar Islam: Analisis atas Pemikiran Muhammad Arkaoun," Al-Tahrir Jurnal Pemikiran Islam , 23.
} 
diminta member kuliah di Fakultas sastra Universitas Strasbourg $(1956-1959){ }^{25}$

Di Universitas Sarbonne inilah Arkoun memperoleh gelar Doktor sastra pada 1669 dengan disertasinya mengenai humanisme salam pemikiran etika Ibnu Miskawayh seorang pemikir Arab abad X Masehi yang menekuni antara lain bidang kedokteran dan filsafat. Judul disertasi tersebutadalah L'Humanisme Arabe au IVe/ Xe sience: Miskawayh philosope et historian. ${ }^{26}$

Sebenarnya penelitian disertasinya itu sudah ia persiapkan jauh-jauh sebelumnya, terbukti pada 1961 Arkon telah menyelesaikan terjemahan, membuat pengantar dan member catatan atas karya Miskawayh dari bahasa Arab, Tahzib al-Akhlaq kedalam bahasa Prancis dengan judul Traite d'Ethique (traduction francaise avec introduction et notes du Tahzib al-Akhlaq de Miskawayh. Dua tahun kemudian ia menulis sebuah buku tentang pemikiran Islam klasik yaitu Aspect de la pense muselman clasique. ${ }^{27}$

Jenjang pendidikan dan pergulatan ilmiah yang ditempuh Arkoun membuat pergaulannya dengan tiga bahasa (Berber Kabilia, Arab dan Prancis) dan tradisi serta kebudayaannya menjadi semakin erat. Pada kemudian hari, inilah yang cukup mempengaruhi perhatiannya yang begitu besar terhadap peran bahasa dalam pemikiran dan masyarakat manusia. Ketiga bahasa tersebut mewakili tiga tradisi, yaitu orientasi budaya, cara berpikir dan cara memahami yang berbeda bahasa Berber Kabilia merupakan alat untuk mengunkapkan berbagai tradisi dan nilai mengenai kehidupan social dan ekonomi yang sudah ribuan tahun usianya, bahasa Arab merupakan alat untuk melestarikan tradisi keagamaan Islam di Aljazair dan di berbagai belahan dunia Islam lainnya. Adapun bahasa Prancis merupakan bahasa administrasi pemerintahan serta alat untuk mengenal nilai-nilai dan tradisi keilmuan Barat terutama Prancis. ${ }^{28}$

Pada tahun 1961, Arkoun dipercaya menjadi dosen Universitas tempat ia belajar sampai 1969. Dari tahun 1970-1972, Arkoun mengajar di Universitas Lyon., kemudian kembali ke Paris sebagai guru besar sejarah pemikiran islam di Universitas Sarbonne

\footnotetext{
${ }^{25}$ Moh.Fauzan dan Muhammad Alfan, Dialog Pemikiran Timur Barat, 214.

${ }^{26}$ Baedhowi, Humanisme Islam, Op.cit, 29.

${ }^{27}$ Baedhowi, Humanisme Islam, 30.

${ }^{28}$ Moh. Fauzan Januri dan Muhamad Alfan, Dialog Pemikiran Timur Barat, 215.
} 
Nouvelle. Arkoun juga menjadi guru bahasa Arab dan peradaban Islam di Universitas Paris VIII (1972-1977). ${ }^{29}$

Selain mengajar, Arkoun juga mengikuti berbagai kegiatan ilmiah dan menduduki jabatan penting di dunia akademis dan masyarakat. Dia menjabat sebagai direktur ilmiah jurnal Arabica, anggota Panitia Nasional Perancis untuk Etika dan Ilmu Pengetahuan Kehidupan dan Kedokteran,anggota Majelis Nasional Perancis untuk AIDS dan anggota Legiun Kehormatan Perancis (chevalier de la Legion d'honneur). Dia pernah mendapat gelar kehormatan, diangkat sebagai Officer des Palmes Academiques, sebuah gelar kehormatan Perancis untuk tokoh terkemuka di dunia universitas dan pernah menjabat sebagai direktur Lembaga Kajian Islam dan Timur Tengah pada Universitas Sorbonne Neuvelle (Paris). Sosok Arkoun yang demikian ini, dapat dinilai sebagai cendekiawan yang engage, melibatkan diri dalam berbagai kegiatan dan aksi yang menurutnya penting bagi kemanusiaan, sebab baginya pemikiran dan aksi harus saling berkaitan. $^{30}$

Penjelajahan Arkoun meliputi fisik dan intelektual. Setelah pensiun dari universitas Sarbonne pada awal 1990-an, dia mengajar di London dan Amsterdam, dan terus menyebarkan pesan-pesannya ke seluruh benua ini tanpa berharap akan mendapat sambutan. Di Barat, Arkoun masih berperan sebagai penentang kecenderungan Orientalisme. Dan di Timur Tengah dia merasa tak nyaman (atau tak diterima) di negeri-negeri di mana Islam versi resmi atau gerakan fundamentalis mencegah digelarnya diskusi tentang isu-isu yang dilontarkannya. ${ }^{31}$

Arkoun sering diundang dan menjadi dosen tamu di sejumlah universitas di luar Perancis, seperti university of California di Los Angeles, Princeton University, Temple University di Philadelphia, Lembaga Kepausan untuk studi arab dan Islam di Roma dan Universitas Katolik Louvain-La-Neuve di Belgia. ${ }^{32}$

Dalam konteks Indonesia, pemikiran Arkoun pertama kali dikenal pada tahun 1987 dalam sebuah diskusi di Yayasan Empati.

${ }^{29}$ Ahmad Munir, Kritik Nalar Islam, Op.Cit, 24.

${ }^{30}$ Ratna Widayati, Muhammed Arkuon; Biografi dan Pemikiran, Artikel Diakses pada 1 Desember dari https://afidburhanuddin.files.wordpress.com/2012/11/arkoun_ed.pdf.

${ }^{31}$ Robert D. Lee, Mecari Islam Autentik: dari Nalar Puitis Ikbal hingga Nalar Kritis Arkoun, (T.tp.: Mizan, t.t.), 195.

${ }^{32} \mathrm{Ibid}$. 
Adalah Muhammad Nasir Tamara yang memperkenalkannya pertama kali dengan menulis artikel yang berjudul Mohammed Arkoun dan Islamologi Terapan. Arkoun sendiri sudah dua kali menngunjungi Indonesia pada acara seminar tentang "contemporary expressing of Islam in Building" (Yogyakarta, November 1992) dan dalam rangka pemberian Aga Khan untuk arsitektur (Yogyakarta dan Solo, November 1995). ${ }^{33}$ Di dalam reverensi yang lain disebutkan bahwa Arkoun juga pernah hadir di Jakarta menjadi pembicara dalam seminar "konsep Islam dan modern tentang pemerintahan dan demokrasi" pada tahun 2000 (senin, 10/4) kehadirannya atas undangan yayasan 2020 yang bekerja sama dengan Geothe Institute, Friendrich Nauman Stiftung, British Council dan Depertemen Agama. Ramainya peserta yang hadir dalam seminar tersebut menjadi bukti besarnya pengaruh Arkoun ini di Indonesia. ${ }^{34}$

Dalam menjalani profesinya sebagai pengajar, Arkoun selalu menyampaikan pendapatnya secara logis berdasarkan analisis yang memiliki bukti dan interaksi falsafati-religius sehingga dapat membangkitkan kebebasan berbicara dan berekspresi secara intelektual, serta tentu saja membuka peluang terhadap kritik. ${ }^{35}$

Secara cemerlang, Arkoun mengakui dirinya sebagai sejarawan-pemikir dan bukan sebagai sejarawan-pemikiran. Sejarawan pemikiran bertugas hanya untuk menggali asal-usul dan perkembangan pemikiran (sejarawan murni), sementara sejarawanpemikir dimaksudkan sebagai sejarawan yang setelah mendapatkan tanda tanda objektif, ia juga bisa mengolah data tersebut dengan memakai analisis filosofis. Dengan kata lain, seorang sejarawan pemikair bukan hanya bertutur tentang sejarah pemikiran belaka secara pasif, melainkan juga secara aktif bisa bertutur dalam sejarah. ${ }^{36}$

\section{Kerangka Pemikiran Arkoun}

Kegelisahan Arkoun yang mewarnai hampir seluruh pemikirannya merupakan kenyataan adanya dikotomi-dikotomi di dalam masyarakat, khususnya masyarakat muslim. Dikotomi tersebut Op.Cit, 172.

${ }^{33}$ Muhaemin Latif, Membumikan Teeologi Islam dalam Kehidupan Modern,

${ }^{34}$ Lihat: Arkoun, Telah Tiada dan Telaah Kritis Pemikirannya, Inpasonline, 20/09/10, senin 20 September 2010, 23:115.

${ }^{35}$ Moh. Fauzan Januri dan Muhammad Alfan, Dialog Pemikiran Timur Barat, 216.

${ }^{36}$ Hermeneutika Muhamed Aekoun (Sekedar Pengantar), Op.Cit, 12 of 10. 
secara garis besar banyak bersentuhan dengan persoalan-persoalan particularity versus (vs) universality, dan marginality vs centrality. ${ }^{37}$

Problem ini tercermin dari adanya pembagian dunia secara berhadap-hadapan, seperti Sunni dengan Syi'i, kaum mistik dengan kaum tradisionalis, muslim dengan nonmuslim, Berber (non-Arab) dengan Arab, Afrika (Asia) dengan Eropa dan sebagainya. Oleh karena itu, dunia yang di tuju oleh Arkoun adalah dunia yang tidak ada pusat, tidak ada pinggiran, tidak ada kelompok yang mendominasi, tidak ada kelompok yang terpinggirkan, tidak ada kelompok yang superior, dan tidak ada kelompok yang inferior di dalam menghasilkan sebuah kebenaran.

Arkoun berusaha mengajukan pertanyaan yang kritis kepada kita, yaitu "Bagaimana seluruh manusia bisa menjadi dirinya sendiri dengan identitas sendiri tanpa menyendiri dari pada tetangga dan sesama manusia lainnya?" Bagi orang Islam, Arkoun bertanya-tanya,"Dapatkah identita muslim didamaikan dengan identitas non muslim?"38

\section{Metodelogi dan Pendekatan dalam Pemikiran Arkoun}

Metodologi dam pendekatan yang dilakukan oleh Mohammed Arkoun, sedikit banyak telah dipengaruhi oleh dua kekuatan tradisi pemikiran yang telah ada, yaitu tradisi pemikiran budaya Timur Tengah Kuno yang memilik tempat khusus di dalam pemikiran Yunani dan tardisi pemikiran monoteisme yang dibawa oleh para nabi. Sehingga Arkoun mengemukakan bahwa dirinya sebagai pengguna metodologi historis-kritis yang mencoba merespon rasa keingintahuannya secara modern, karena metodologi ini nilainya dapat menelusuri studi tentang pengetahuan mistis yang tidak hanya dibatasi dengan mentalitas lama. Dengan demikian, menurut Arkoun, saat ini usaha intelektual utama yang harus dipresentasikan secara luas ke dalam pemikiran tentang Islam dan tentang agama lainnya adalah bagaimana mengevaluasi karakteristik-karakteristik dari sistem ilmu pengetahuan yang historis dan mistis dengan perspektif epistimologis yang baru. ${ }^{39}$

Tujuan yang ingin diraih dengan proyek ini adalah untuk mengembangkan sebuah strategi epistimologi baru di bidang studi perbandingan terhadap budaya melalui contoh yang dikembangkan

\footnotetext{
Timur Barat, 216.

${ }^{38}$ Moh. Fauzan Januri dan Muhammad Alfan, Dialog Pemikiran

Timur Barat, 216.

${ }^{39}$ Ratna Widayanti, Mohammed Arkoun; Biografi dan Pemikiran, 3
}

${ }^{37}$ Moh. Fauzan Januri dan Muhammad Alfan, Dialog Pemikiran 
oleh Islam sebagai agama dan sebagai produk sosial sejarah. Arkoun mengajukan pendekatan historis, sosiologis, dan antropologis dengan tidak menghilangkan betapa pentingnya pendekatan teologis dan filosofis. Dan pendekatan yang dilakukan oleh Arkoun ini bertujuan untuk memperkaya pendekatan tersebut dengan memasukkan keadaan-keadaan historis dan sosisl yang selalu dipraktekkan dalam Islam. Metode Arkoun ini disebut sebagai salah satu bentuk metode dekonstruksi. Strategi dekonstruksi tersebuthanya mungkin dilakukan dengan epistimologi modern yang kritis. ${ }^{40}$

Dengan demikian, nalar kritis seseorang harus dibebaskan dari ontologi, transendentalisme, dan substansionalisme yang mengikat, membatasi kebebasan dan memenjarakannya, terutama di dalam nalar yang dielaborasikan di berbagai macan teologi melalui metafisika dan logika Yunani. Di dalam melaksanakan proyek besar tersebut, menurut Arkoun harus dimulai dari suara atau teori yang dianggap Arkoun memiliki otoritas, karena hanya dia yang dapat memberikan penampakan Islam dan mentalitas modern yang ilmiah, dan sekaligus juga di dalam pengalaman keagamaan orang Islam. Dalam bahasa lain, agar kita dapat mengartikulasi visi modern tentang Islam yang sekaligus bisa memberikan pada komunitas. ${ }^{41}$

Enam garis pemikiran (six heuristic lines of thinking) yang diajukan Arkoun untuk merekapitulasikan ilmu pengetahuan Islam dan mengkonfrontasikannya dengan ilmu pengetahuan kontemporer. $\mathrm{Hal}$ itu yang mendasari pentingnya modernitas dilakukan bagi kemajuan pemikiran Islam. Enam garis pemikiran tersebut adalah sebagai berikut:

1. Di dalam masyarakat, manusia menggunakan berbagai cara yang berubah-ubah, yang dialihbentukkan menjadi sebuah tanda, di mana. sistem tanda itu ditampilkan melalui bahasa. Tanda-tanda tersebut merupakan persoalan yang radikal bagi ilmu pengetahuan yang kritis dan terkendali. Persoalan ini muncul mendahului berbagai usaha untuk menafsirkan wahyu. Kitab-kitab suci itu sendiri dikomunikasikan melalui bahasa-bahasa alami yang digunakan sebagai sistem tanda dan telah diketahui bahwa setiap tanda merupakan locus dari tindakantindakan convergent yang berlaku di semua hubungan antara bahasa dan pemikiran. Persoalan tanda dalam bahasa merupakan isu di dalam pendekatan strukturalis-semiotik dari metodologi linguistik yang antropologis. Menurut Greimas, J. Courtes, agama merupakan lahan

\footnotetext{
${ }^{40}$ Ratna Widayanti, Mohammed Arkoun; Biografi dan Pemikiran, 4 ${ }^{41}$ Ratna Widayanti, Mohammed Arkoun; Biografi dan Pemikiran, 4.
} 
subur bagi analisis semiotis, sebab tanda akan memainkan peran penting di dalamnya, semiotik dapat dianggap sebagai ilmu pengetahuan signifikasi yang hanya menekankan aspek tertentu dari jangkauan ilmu pengetahuan tanda. Semiotik, secara radikal juga dianggap sebagai ilmu yang membahas segala gejala budaya sebagai proses komunikasi. ${ }^{42}$

2. Semua hasil semiotik manusia dalam proses penampakan sejarah dan budaya merupakan sasaran dari perubahan sosial yang oleh Arkoun disebut sebagai historicity. Dan sebagai artikulasi makna bagi alat sosial dan budaya, teks alQuran juga merupakan sasaran dari historicity. Dengan demikian, tidak ada akses dari keberadaan historis kita terhadap fenomena absolut di luar fenomena dunia wilayah kita. Penampakan-penampakan yang ditampilkan oleh ontologi (keberadaan kebenaran yang pertama) dan transendensi milik nalar teologis dan nalar metafisis tentu telah meniadakan historisitas sebagai dimensi kebenaran. Hal ini terjadi karena, karena alat-alat, konsepkonsep, definisi-definisi dan postulat-postulat yang terus berubah digunakan untuk mengetahui kebenaran. Hal ini bertentangan dengan semua pemikiran abad pertengahan yang didasarkan pada esensiesensi dan substansi-substansi yang telah mapan. Konsep wahyu harus ditinjau ulang menurut sistem semiotik yang menjadi sasaran historisitas. Definisi Aristotelian tentang logika formal dan kategori abstrak, harus direvisi dalam konteks teori semiotik tentang makna dan historisitas nalar. Garis pemikiran kedua ini merupakan pendekatan post-strukturalis dekonstruksionis dari linguistik kritis. Di dalamnya ada, demistifikasi dan demitologisasi fenomena kitab suci dari semua sakralisasi dan interpretasi yang dilahirkan oleh nalar teologis. ${ }^{43}$

3. Terdapat berbagai tingkatan dan bentuk nalar yang berinteraksi dengan angan-angan (imagination) sebagaimana yang telah ditunjukkan di dalam ketegangan antara logos (kalam yang dipedebatkan) dengan mythos (kalam yang tidak dapat dipertanyakan), simbol dengan konsep, metafora dengan realitas, makna dhahir dan makna batin pada sejarah Islam. Imagination dan imaginaire dianggap sebagai bagian dinamis dari ilmu pengetahuan dan

${ }^{42}$ Moh. Fauzan Januri dan Muhammad Alfan, Dialog Pemikiran

Timur Barat, 222.

${ }^{43}$ Moh. Fauzan Januri dan Muhammad Alfan, Dialog Pemikiran

Timur Barat, 222. 
tindakan. Ideologi-ideologi yang membuat mobilisasi, baik dalam kerangka agama maupun dalam kerangka sekuler, dihasilkan dan digunakan oleh imaginaire sosial. pengaruh maginaire tersebut sangat menentukan di dalam masyarakat Muslim seperti di Timur Tengah, karena budaya rasional hanya mempunyai pengaruh yang sedikit, berbeda dengan masyarakat Barat yang meski juga masih memiliki imaginaire. Garis pemikiran seperti ini merupakan pendekatan mitis dalam metodologi analisis antropologis. ${ }^{44}$

4. Discours sebagai artikulasi ideologis tentang realitas sebagaimana yang dipersepsikan dan digunakan oleh kelompok-kelompok yang saling berkompetisi itu, datang mendahului iman yang diekspresikan, ditemukan dan diaktualisasikan di dalam dan melalui discours. Sebaliknya, setelah mengambil bentuk dan akar dari discourse Arkoun ...keagamaan, politik dan keilmuan, iman kemudian memberikan arah dan postulat-postulat bagi dicsours dan perilaku-perilaku yang mengikutinya (baik individu maupun kolektif). Dengan demikian, iman merupakan kristalisasi dari angan-angan, penampilanpenampilan, dan ide-ide yang diberikan secara umum oleh tiap kelompok yang berada di dalam pengalaman sejarah. Dari garis keempat ini, dapat diketahui bahwa pendekatan Arkoun adalah poststrukturalis semiotis sosiokritis dengan metodologi linguistik kritis. Dan perlu diketahui bahwa kata discours menuntut adanya pembicara yang menyampaikan pesan (pengirim), penerima pesan yang bereaksi terhadap pesan yang disampaikan sesuai dengan situasi (konteks) pembicaraan yang berupa suatu lingkungan semiologis yang menentukan emisi dan penerimaan pesan, serta menuntut adanya bahasa yang digunakan sebagai alat penyampaian pesan yang tentu sangat terkait erat dengan cara pandang dan cara pikir para penuturnya. ${ }^{45}$

5. Saat ini, kita sedang mengalami krisis legitimasi sebab sistem legitimasi tradisional yang dikemukakan oleh ilmu Ushul Ad-Din dan Ushul Al-Fiqh tidak lagi memiliki relevansi historis. Belum ada sistem legitimasi baru yang di bangun dengan suara bulat di kalangan umat. Sekalipun demikian, menurut Arkoun, saat ini kita sedang tertantang untuk mengajukan sebuah sistem legitimasi bagi ilmu pengetahuan, terutama bagi pemikiran Islam dengan memakai prinsip-prinsip epistemologi kritis. Hal yang perlu dipertanyakan lebih lanjut adalah

\footnotetext{
${ }^{44}$ Nuril Hidayati, Modernitas dalam Pemikiran Islam Mohammad Arkoun, 10, online diakses pada 1 Desember 2017.

${ }^{45}$ Nuril Hidayati, Modernitas dalam Pemikiran Islam Mohammad Arkoun, 11.
} 
apa persyaratan teoretis dari sebuah teologi yang modern, yang ditujukan tidak hanya pada lembaga-lembaga polotik, tetapi juga pada ilmu pengetahuan yang universal dari tiga agama wahyu (Islam, Yahudi, dan Kristen)? Pendapat Arkoun ini bertentangan dengan jaminan teologis dari pengwahyuan atau ontologi klasik mengenai keberadaan awal dari neo-platonik yang didasarkan pada legitimasi syariat yang tidak dapat dipertanyakan sehingga Arkoun menggugat adanya legitimasi kekuasaan yang dimonopoli oleh sekelompok orang. Garis pemikiran kelilma ini merupakan pendekatan kritik epistemologis dari metodologi historis filosofis. Titik sentral pemikiran Arkoun terletak pada kata kunci kritik epistemologis yang digunakan dalam banyak konteks yang berbeda-beda dan barangkali terinspirasi dari istilah "kritik" dalam pemikiran Immanuel Kant, sekalipun bisa jadi memang karena budaya kritik yang pernah hidup subur di kalangan umat Islam. Kritik epistemologis ditujukan pada bangunan keilmuan agama secara keseluruhan, yang dilihat Arkoun sebagai produk sejarah yang terkait dengan ruang dan waktu tertentu. ${ }^{46}$

6. Pencarian terhadap makna tertinggi bergantung pada pertanyaan radikal mengenai relevansi dan eksistensi sebuah makna tertinggi tersebut. Kita tidak berhak menyangkal adanya kemungkinan munculnya makna tertinggi. Pertanyaan yang dapat kita ajukan berkenaan dengan cara mendasarkan seluruh pemikiran kita di atas postulat mengenai adanya makna tertinggi tersebut. Menurut Arkoun, kita mempunyai tanggung jawab terhadap terwujudnya nalar kritis. Oleh karena itu, kita bertanggung jawab untuk mencari pemahaman yang lebih baik tentang hubungan antara makna dan realit as. Pertamatama, kita harus meningkatkan peralatan intelaktual., yaitu yang menyangkut mengenai kosakata, metodologi, strategi produser, definisi, dan wawasan penelitian. Dengan begitu, berarti Arkoun mengakui adanya "petanda transcendental" sebagai petanda terakhir yang merupakan pendekatan yang melampaui batas semiotika dalam metodologi structural linguistik. Dengan memerhatikan enam garis pemikiran Arkoun, dapat ditarik sebuah garis lurus bahwa pendekatan dan metodologi pemikiran Arkoun adalah multidisiplin yang bersifat antropologis. ${ }^{4 T}$

\footnotetext{
${ }^{46}$ Moh. Fauzan Januri dan Muhammad Alfan Dialog Pemikiran Timur Barat, 224-225

${ }^{47}$ Moh. Fauzan Januri dan Muhammad Alfan Dialog Pemikiran Timur Barat, 224-225.
} 


\section{E. Akar Epistemologi Arkoun}

Kritik nalar dalam istilah filsafat adalah "kritik epistemologi" itu sendiri, yaitu kritik terhadap metodologi yang kemudian melahirkan sebuah ilmu. Oleh karena itu munculnya kritik nalar merupakan respon ketidakpuasan atas metodologi kajian islam yang berkembang. Analisis epistemologis dengan mengedepankan kritik harus diterapkan pada teks, baik teks sakral maupun profan, historis maupun filosofis, teologis maupun yuridis, sosiologis maupun antropologis. ${ }^{48}$

Menurut Arkoun, Islam bukanlah agama yang terorganisasi secara kaku dan dogmatis. Dalam perjalanan historisnya, melalui jalur kekuasaan, Islam telah menjadi dogma mati untuk kepentingan kekuasaan itu sendiri. Oleh karena itu, dari sudut pandang sejarah, pemikiran Islam telah mandek, terkotak-kotak, tertutup, sempit, dan logosentris. ${ }^{49}$

Oleh karena itu, Arkoun mencanangkan sebuah proyek besar yang disebutnya "kritik nalar Islam" dan "pembukaan kembali pintu ijtihad". Dalam kenyataannya, ijtihad hanyalah memenuhi tuntutan ideologis dari penguasa. Oleh karena itu, ia mengusulkan agar tugas ijtihad diperluas lagi. ${ }^{50}$

Keprihatinan Arkoun terhadap nalar Islam yang berkembang ditimbulkan oleh persoalan-persoalan berikut: mengapa ilmu-ilmu agama Islam seperti fikih, kalam, falsafah, tasawuf, tafsir itu jalan di tempat, baik dari segi bentuk maupun metodologinya. Sejak "ilmuilmu" itu disusun, sampai abad ke-18, belum ada perubahan yang cukup signifikan. Bahkan format itu pulalah yang masih diikuti, dipelajari dan ditekuni sekarang. Padahal kehidupan manusia telah berubah sedemikian rupa, baik dari segi kualitas maupun kuantitasnya. ${ }^{51}$

Mengapa para ulama fikih, kalam, filsafat, tafsir dan akhlak tidak pernah memanfaatkan hukum-hukum dan temuan-temuan ilmu sosial sebagai bahan pertimbangan untuk memodifikasi, memperbaharui, menyegarkan dan membangun kembali konstruksi

\footnotetext{
${ }^{48}$ Ahmad Munir, "Kritik Nalar Islam: Analisis atas Pemikiran Muhammad Arkaoun", Op.Cit, 31.

${ }^{49}$ Siti Rohmah Soekarba, Kritik Pemikiran Arab: Metode Dekonstruksi Mohammen Arkoun, Op.Cit, 79.

${ }^{50}$ Siti Rohmah Soekarba, Kritik Pemikiran Arab: Metode Dekonstruksi Mohammen Arkoun, 79.

${ }^{51}$ Ahmad Munir, "Kritik Nalar Islam: Analisis atas Pemikiran Muhammad Arkaoun", Op.Cit, 33.
} 
keilmuan dan metodologi studi keislaman? Samakah pengalaman beragama pada abad klasik-skolastik dengan pengalaman beragama era modern dan teknologi kontemporer? Samakah kualitas manusia era klasik dengan era modern, begitu juga problema dan tantangan yang mereka hadapi? Jiak tidak, lalu mengapa konstruksi epitemologi ilmuilmu agama islam itu tidak berubah? Tidak bisakah rancangan bangunan epistemologi ilmu-ilmu keislaman itu dikembangkan sehingga dapat beradaptasi dangan wacana kontemporer?

Arkoun menyesalkan efek dari pembukuan dan pembakuan ajaran agama yang dianggap standar. Terutama standarisasi doktrin islam yang dilakukan oleh para ulama Abasiyah, yang telah meradupkan dinamika wacana Islam sebagaimana yang terjadi dimasa Rasululla dan masa sahabat. ${ }^{52}$

Tidak hanya sampai di situ, ia juga banyak mencela kajiankajian para ulama terdahulu yang dianggapnya sudah tidak relevan. Dalam bukunya, Rethinking Islam: Common question, Uncommon answer, today (boulder: Westview Press, 1994), Arkoun berkata:

"Saya tidak mengatakan bahwa al-Quran tidak relevan... yang saya katakan adalah bahwa pemikiran yang dipakai oleh para teolog dan fuqaha' untuk menafsirkan al-Quran tidak relevan. Sebab, sekarang ilmu baru seperti antropologi, tidak mereka kuasai. Kita juga memiliki linguistik baru, metode sejarah, biologi_semuanya tidak mereka kuasai. Dengan episteme yang sama, yakni berdasarkan karakter teksnya, al-Quran yang berbahasa Arab, dianggap mempungai persamaan dengan teks-teks sastra, atau kitab suci lainnya". 53

Meskipun Arkoun mengkritik secara total pemikiran teologi Islam klasik, ia juga menghargai semangat keagamaan yang hidup pada waktu itu. Etos keilmuan masyarakat Islam klasik memang mendapat pengakuan umum dalam dunia kesarjanaan modern bahwa mereka mewarisi, mengembangkan serta mewariskan kekayaan intelektual umat manusia. Lebih dari itu, menurut Arkoun, masyarakat Islam klasik adalah kelompok manusia pertama yang menginternasionalkan ilmu pengetahuan yang sebelumnya bersifat parokialistik, bercirikan kenasionalan. Semangat keagamaan tersebut idealnya dipadukan dengan pemikiran Barat yang modern yang sifatnya rasional dan kaya

\footnotetext{
${ }^{52}$ Ahmad Munir, "Kritik Nalar Islam: Analisis atas Pemikiran Muhammad Arkaoun”,,33.

${ }^{53}$ Arkoun, Telah Tiada dan Telaah Kritis Pemikirannya, Inpasonline.com, 20 September2010, 23:5l.
} 
akan sikap kritik sehingga agama dapat dipahami lebih dalam dan membongkar ketertutupan dan penyelewengan pemahaman. ${ }^{54}$

\section{F. Pemikiran-pemikiran Penting Arkon}

\section{Pemikiran Arkoun tentang Wahyu}

Kritik terhadap konsep wahyu dilatarbelakangi oleh kegelisahan Arkoun terhadap sistem epistemologi Islam. Selama berabad-abad lamanya, umat Islam menurut Arkoun mangalami problem sistem epistemologi. Persoalan mendasar ini, baginya menjadi faktor utama keterbelakangan dunia Islam. Sistem yang disebut Arkoun, ortodoksi Islam, menghambat gerak laju nalar untuk maju dalam mengejar ketertinggalannya dari Barat.

Maka tugas utama pemikir Islam menurut Arkoun adalah membongkar epistemologi Islam tradisional karena dianggap telah membentuk ortodoksi Islam yang telah mengendap lama dalam nalar umat Islam. sumber utama sistem ortodoksi yang rigid itu menurutnya adalah posisi al-Quran. Dogma-dogma kaku dalam agama tidak lain lahir karena ketidakmampuan muslim untuk menangkap pesan orisinil al-Quran sebagaimana pada periode awal (periode kenabian) sebagai korpus yang terbuka. Sehingga peradaban Islam termasuk dikategorikan peradaban teks yang semua problem dikembalikan kepada teks. ${ }^{55}$

Arkoun memahami wahyu adalah sebagai amanat yang sangat kaya dan luas sehingga dapat diberikan makna konkret dalam setiap keadaan yang berbeda yang dilalui umat manusia. ${ }^{56}$ Mengenai wahyu, Arkoun membaginya dalam dua peringkat. Pertama adalah apa yang disebut dengan al-Qur'an sebagai Umm al-Kitab (induk kitab) (QS, 13:39; 43:4). ${ }^{57}$ Peringkat kedua adalah berbagai kitab termasuk Bible, Gospel dan al-Qur'an. Umm al-Kitab adalah kitab langit, wahyu yang sempurna, dari mana Bible berasal. Pada peringkat pertama (Umm alKitab) wahyu bersifat abadi, tidak terikat waktu serta mengandung kebenaran tertinggi. Namun menurut Arkoun, kebenaran absolut ini Op.Cit, 175 .

${ }^{54}$ Muhaemin Latif, Membumikan Teeologi Islam dalam Kehidupan Modern,

${ }^{55}$ Kholili Hasib, Mohammed Arkoun dan Desakralisasi Al-Qur'an, Inpasonline.com, selasa, 21 September 2010, 10:14, 1 of 12.

${ }^{56}$ Ahmad Munir, "Kritik Nalar Islam, Op.Cit, 28.

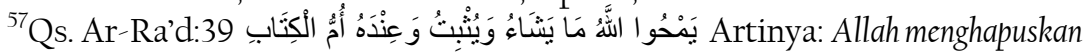
apa yang Dia kehendaki dan menetapkan, dan di sisi-Nya-lah terdapat Ummul-Kitab. Qs.Az-

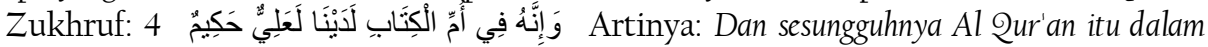
induk Al Kitab di sisi Kami, adalah benar-benar tinggi dan amat banyak mengandung hikmah. 
diluar jangkauan manusia, karena bentuk wahyu yang seperti itu diamankan dalam Lawh Mahfuz (Preserved Tablet) dan tetap berada bersama dengan Tuhan sendiri. Wahyu hanya dapat diketahui oleh manusia melalui bentuk peringkat kedua. Peringkat kedua ini dalam istilah Arkoun dinamakan "edisi dunia" (edition terrestres). Menurutnya pada peringkat ini wahyu telah mengalami modifikasi, revisi dan subsitusi. ${ }^{58}$ Dapat ditarik kesimpulan, bahwa Arkoun berkeyakinan ada perbedaan antara edisi langit dengan edisi dunia yang ditransmisikan kepada para Nabi. Tuhan menurunkan wahyunya ke bumi dalam bentuk bahasa manusia, yang tentu berbeda dengan esensi dengan yang di Lauh al-Mahfudz. Sedangkan bentuk edisi kedua adalah fenomena wahyu dalam sejarah. Ia adalah realitas firman Allah. Tuhan mengkomunikasikan kehendak-Nya kepada manusia melalui para nabi. Untuk itu, Tuhan memakai bahasa yang dapat dimengerti manusia, tetapimengartikulasi kalimat-kalimat-Nya. Arkoun mengatakan:

"tugas para nabi, seperti nabi Musa, 'Isa, dan Muhammad, hanyalah menyampaikan sebuah wacana yang diwahyukan kepada mereka sebagai bagian dari ucapan-ucapan-Nya yang tidak diciptakan, tidak terbatas dan koeternal".

Dari pernyataan tersebut secara jelas, Arkoun menyebutkan alQur'an atau kitab-kitab lainnya adalah wacara firman Tuhan. Ia menggunakan term yang dipakai Faucault, yaitu discourse (wacana). Jika al-Qur'an yang turun kepada nabi Muhammad SAW adalah wacana maka, ia termasuk produk historis - dalam istilah Nasr Hamid Abu Zayd, muntaj tsaqafi (produk budaya). Oleh sebab itu, oleh Arkoun, wahyu dalam tataran ini telah tereduksi, ia tidak mengungkapkan seluruh kata-kata Tuhan sebagaimana tercantum dalam Ummu al-Kitab di Lauh Mahfudz: ${ }^{59}$

Untuk kepentingan analisisnya, Arkoun membedakan tiga tingkatan anggitan tentang wahyu. Pertama, wahyu sebagai firman Allah yang transenden; tidak terbatas dan tidak diketahui oleh manusia. Untuk menunjukkan realitas wahyu seperti ini, biasanya dipakai anggitan Al-Lawh Al-Mahfudh atau Umm Al-Kitab. Kedua, wahyu yang diturunkan dalam bentuk pengujaran lisan dalam realitas sejarah yang disebut sebagai discours religious dan berfragmen dalam bentuk kitab Bible (Taurat dan Zabur), injil dan al-Quran. Ketiga, wahyu yang

\footnotetext{
${ }^{58}$ Badrus Syamsi, Metodologi Studi al-Quran Muhammad Arkoun: Kajian Kritis, Inpasonline.com, Selasa 21 September 2010, 22:05, 1 of 12.

${ }^{59}$ Kholili Hasib, Mohammed Atkoun dan Desakralisasi al-Quran, 7 of 12.
} 
direkam di alam catatan yang menghilangkan banyak hal, terutama situasi pembicaraan (sementara asbab alnuzul belum dapat mengembalikan hal-hal yang hilang ketika suatu pembicaraan direkam ke dalam tulisan). ${ }^{60}$

Wahyu jenis ketiga adalah merujuk kapada wahyu yang tertulis dalam mushaf yang oleh Arkoun disebut sebagai Kanon Resmi Tertutup (Official Closed Canons). Mushaf yang dimaksud adalah mushaf Usman bin Affan. ${ }^{6}$ Wahyu pada tatanan ini, sudah banyak yang teredukasi oleh prosedur-prosedur manusiawi. Inilah bentuk fisik wahyu, yang terkondisikan oleh kresi manusiawi yang tidak sempurna. Menurut Arkoun, saat ini melalui wahyu bentuk mushaf inilah manusia dapat mengakses langsung ujaran Tuhan yang transenden. Wahyu pada mulanya berbentuk ujaran lisan pada masa kenabian kemudian ditulis di atas perkamen atau kertas yang dijadikan buku. Buku ini disebut oleh pengikutnya "Kitab Suci".

Arkoun merinci mekanisme wahyu berdasarkan surat 42 (AsySyura) ayat $51 .{ }^{63}$ Menurutnya kosa kata wahyu yang digunakan oleh ayat sulit untuk diterjemahkan ke dalam bahasa-bahasa manusia yang tidak sakral, itulah sebabnya dia tidak menterjemahkan kata wahyu. Ia hanya berpendapat bahwa wahyu atau al-Quran sebagai bacaan yang di artikulasi(diucapkan) dalam bahasa manusia dan dikomunikasikan kepada para nabi secara langsung atau dengan memalalui perentaraan seorang malaikat. Padahal ayat ini manjelaskan turunnya wahyu dalam tiga cara. Pertama, informasi wahyu dengan jalan ilham yaitu menyampaikan makna tertantu ke hati Nabi sekaligus bersama ilmu yang yakin hal itu hanya datang dari Allah, baik dalam mimpi maupun saat terjaga (sadar). Kedua, pembicaraan lewat balik hijab di mana

${ }^{60}$ Moh. Fauzan Januri dan Muhammad Alfan Dialog Pemikiran

Timur Barat, 226.

${ }^{61}$ Kodifikasi ini dilakukan karena terjadi sebuah peristiwa yang tidak terpikirkan oleh seorang sahabat pun sebelumnya. Dalamperang yamamah, sedikitnya 1000 pasukan muslim gugur, 450 diantaranya dari kalangan sahabat. Informasi ini sampai ketelinga Umar bin Khaththab, lalu ia memikirkan akan nasib al-Qur'an. Lihat Badrus Syamsi, MetodologiStudial-Quran Muhammad Arkoun, 3 of 12.

${ }^{62}$ Kholili Hasib, Mohammed Arkoun dan Desakralisasi Al-Qur'an, Op.Cit, 8 of 12.

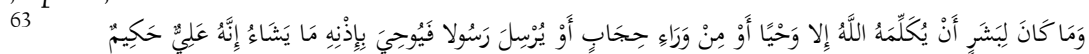
artinya: Dan tidak mungkin bagi seorang manusiapun bahwa Allah berkata-kata dengan dia kecuali dengan perantaraan wahyu atau dibelakang tabir atau dengan mengutus seorang utusan (malaikat) lalu diwahyukan kepadanya dengan seizin-Nya apa yang Dia kehendaki. Sesungguhnya Dia Maha Tinggi lagi Maha Bijaksana. 
Nabi tidak melihat Allah saat berlangsungnya pembicaraan, saperti halnya Nabi Musa saat menerima wahyu pertama kali. Ketiga, penyampaian wahyu lewat malaikat. ${ }^{64}$

\section{Pemikiran Arkoun tentang al-Quran}

Mengenai sejarah al-Quran, Arkoun membaginya menjadi tiga periode: periode pertama berlangsung kepada pewahyuan (610-632 M); periode kedua, berlangsung ketika koleksi dan penetapan mushaf (12$324 \mathrm{H} / 632-936 \mathrm{M})$ dan periode ketiga, berlangsung ketika masa ortodoks(324H/936 M). arkoun menamakan periode pertama sebagai Prophetik Discourse (Diskursus Kenabian) dan periode kedua sebagai Closed Official Corus (Korpus Resmi Tertutup).

Berdasar pada periode tersebut, Arkoun mendefenisikan alQuran sebagai "sebuah korpus yang selesai dan terbuka yang diungkapkan dalam bahasa Arab, diamana kita tidak dapat mengakses kecuali malalui teks yang ditetapkan setelah abad ke 4 H / 10 M". Menurut Arkoun dalam tradisi Muslaim pengumpulan al-Quran mulai pada saat Nabi meninggal pada tahun 632, tetapi ketika beliau hidup tempaknya ayat-ayat tertentu sudah ditulis. Kumpulan-kumpulan parsial dibuat dengan bahan-bahan yang agak tidak memuaskan, karena kertas belum dikenal dikalangan orang Arab dan tersedia bagi mereka baru diakhir abad ke-8. Meninggalnya para sahabat Nabi, yaitu arang-orang yang ikut hijrah bersama beliau dari Mekkah ke Madinah pada tahun 622, dan perdebatan tajam dikalangan umat Islam mendorong khalifah ketiga, Usman, untuk mengumpulkan totalitas wahyu ke dalam satu kompilasi yang disebut mushaf. Kumpulan ini dinyatakan sempurna, selesai dan tertutup dan kompilasi-kompilasi parsial pun dimusnahkan untuk menghindari perbedaan yang akan timbul tentang keotentikan wahyu-wahyu yang dipilih. Dia menegaskan bahwa proses pemilihan dan pemusnahan ni mengharuskan kita bertumpu pada Corpus Resmi yang Tertutup. ${ }^{65}$

Meski dalam sejarah telah terjadi proses 'sakralisasi' mushaf menjadi teks tertutup, namun bagi Arkoun teks al-Quran tetap teks yang terbuka. Oleh sebab inilah, al-Quran telah melahirkan banyak literatur referensi, doktrin dan hukum yang beragam. Itulah sebabnya Arkoun hendak melakukan pemaknaan atau aktualisasi sesuai dengan keadaan nyata. Ia tidak bisa disempitkan menjadi ideologi. Dengan begitu al-Quran menjadi teks yang 'hidup'. Berkaitan dengan

\footnotetext{
${ }^{64}$ Badrus Syamsi, Metodologi Studi al-2uran Muhammad Arkoun, 4 of 12.

${ }^{65}$ Badrus Syamsi, Metodologi Studi al-Quran Muhammad Arkoun, 3 of 12.
} 
pemikiran Islam tradisional yang penuh dengan makna-makna transedensi, maka bagi Arkoun pemikiran tersebut belum tentu sama dengan wahyu ilahi yang sebenarnya. Sebab pembentukan pembentukan pemikiran Islam tidak lepas dariaktualisasi yang dipengaruhi oleh beragam aspek, mulai social, politik dan budaya. Disamping sumber rujukannya adalah kitab tertulis yang menurutnya sudah tereduksi oleh prosedur-prosedur manusiawi. Dari pemikiran demikian, maka Arkoun sebenarnya berpendapat bahwa tafsir, fiqih, tasawuf dan lain-lain adalah produk aktualisasi yang terkait dangan sejarah. Syariah berarti adalah prosuk manusia tersebut adalah dokumen sejarah yang telah melalui proses yang panjang, terkait dengan sosial, generasi serta gerakan pemikiran keagamaan. ${ }^{66}$

Arkoun membedakan antara periode pertama dan periode kedua. Menurut Arkoun, dalam periode diskursus kenabian, al-Quran lebih suci, lebih autentik dan lebih dapat dipercaya disbanding ketika dalam bentuk tertulis. Sebabnya al-Quran terbuka untuk semua arti ketika dalam bentuk lisan, tidak seperti dalam bentuk tulisan. Sedangkan ia menganggap status al-Quran dalam bentuk tulisan telah berkurang dari kitab yang diwahyukan (al-Kitab al-Muhi) menjadi sebuah buku biasa (kitab 'Adi). Arkoun berpendapat bahwa mushaf itu tidak layak untuk mendapatkan stastus kesucian. Tetapi muslim ortodoks meninggikan korpus ini ke dalam sebuah status firman Tuhan.

Pemikiran Muhammad Arkoun telah membuat peradigma baru tentang hakekat teks al-Quran. Pendekatan historis Muhammad Arkoun justru menggiringnya untuk menyimpulkan sesuatu yang ahistoris. Yaitu kebenaran wahyu hanya ada pada level diluar jangkauan manusia. Muhammad Arkoun mengakui kebenaran Umm alKitab hanya ada pada Tuhan sendiri. Ia juga mengakui kebenaran dan kredibilitas bentuk lisan al-Quran, tetapi bentuk itu sudah hilang selama-lamanya dan tidak mungkin ditemukan kembali. Jadi, Pendekatan historis Muhammad Arkoun justru menggiringnya untuk menyimpulkan sesuatu yang ahistoris. Padahal sepanjang zaman fakta historis menunjukkan, kaum muslimin sejak dahulu, sekarang dan akan dating meyakini kebenaran al-Quran Mushaf Utsmani. ${ }^{67}$

\footnotetext{
${ }^{66}$ Kholili Hasib, Muhammad Arkoun dan Desakralisasi al-Quran, Op.Cit, 8 of 12.

${ }^{67}$ Badrus Syamsi, Metodologi Studi al-Quran Muhammad Arkoun, 3 of 12.
} 


\section{a. Cara dan Tujuan Membaca al-Quran Menurut Muhammad Arkoun}

Aturan-aturan metode Arkoun yang hendak diterapkannya kepada al-Quran (termasuk kitab suci yang lainnya) terdiri dari dua kerangka raksasa:

1) Mengankat makna dari apa yang disebut dengan sacra doctrina dalam Islam dengan menundukkan teks al-Quran dan semua teks yang sepanjang sejarah pemikiran Islam telah berusaha menjelaskanya (tafsir dan semua literatur yang ada kaitannya dengan al-Quran baik langsung maupun tidak), kepada suatu ujian kritis yang tepat untuk menghilangkan kerancuan-kerancuan untuk mempelihatkan dengan jelas kesalahan-kesalahan, penyimpangan-penyimpangan dan ketakcukupan-ketakcukupan untuk mengarah kepada pelajaran-pelajaran yang selalu berlaku.

2) Menetapkan kriteriologi yang didalamnya akan dianalisis motifmotif yang dapat dikemukakan oleh kecerdasan masa kini, baik untuk menolak maupun untuk mempertahankan konsepsikonsepsi yang dipelajari. ${ }^{68}$

Dalam mengangkat makna dari al-Quran, hal yang paling pertama yang dijauhi oleh Arkoun adalah pretensi untuk menetapkan "makna sebenarnya dari al-Quran". Sebab, Arkoun tidak ingin membakukan makna al-Quran dengan cara tertentu, kecuali dengan menghadirkan sebisa mungkin aneka ragam maknanya. Untuk itu, pembacaan mencakup tiga saat (moment):

1) Suatu saat linguistis yang memungkinkan kita untuk menemukan keteraturan dasar di bawah keteraturan yang tampak.

Pembacaan linguistik dimulai dengan pengumpulan data-data linguistis dari al-Quran sebagaimana tertulis. Dalam tahap ini, misalnya Arkoun memeriksa tanda-tanda bahasa (modalisateur $d u$ discours) karena "kanon resmi tertutup" ditulis dalam bahasa Arab, maka tanda-tanda bahasa yang harus diperhatikan adalah tanda-tanda (bahasa) bahasa Arab. Menurut Arkoun, semakin kita menegaskan modalisateur du discour, kita semakin memahami maksud (intention) dari locuteur (qo'il atau penutur). ${ }^{69}$

\footnotetext{
${ }^{68}$ Hermeneutika Muhamed Arkoun: Sekedar Pengantar, Op.Cit, 12 of 12 .

${ }^{69}$ Cecep Ramli Bihar Anwar, Muhammad Arkoun: Cara Membaca Al-Qur'an, 11 of 15.
} 
Untuk memasuki proses pengujaran, di antara unsure-unsur linguistik yang diperiksa biasanya adalah determinan (ism ma'rifah), kata ganti orang (pronominal, dlamir), kata kerja (fi'il), sistem kata benda (ism dan musamma), struktur sintaksis dan lain-lain. Pemeriksaan terhadap unsur-unsur linguistik ini dimaksudkan untuk menganalisis aktan-aktan (actants), yaitu pelaku yang melakukan tindakan yang berada dalam teks atau narasi. Dengan kategori aktan, ujaran (Perancis enonce/Inggris utterance) dipandang sebagai suatu hubungan antara berbagai akktan yang membentuknya. Atau dalam kaca mata linguistik, ujaran mau tidak mau harus dilihat dari kategori hubungan antar aktan. Dilihat dari kategori ini, ada tiga poros hubungan aktanaktan. Poros pertama dan yang terpenting adalah poros subyek-obyek dimana orang dapat memeriksa "siapa" melakukan "apa". Poros kedua adalah adalah poros pengirim penerima yang menjawab persoalan siapa melakukan dan untuk siapa dilakukan. Sedangkan poros ketiga dimaksudkan untuk mencari aktan yang mendukung dan menentang subyek, yang berada dalam poros "pendukung-penerima". Ketiga pasangan ini dapat membantu pembaca untuk mengidentifikasi aktan dan kedudukannya. Aktan tidak selalu harus berupa orang atau pribadi, tetapi juga bisa berupa nilai.

Dengan kategori poros aktan pengirim-penerima, misalnya Arkoun mengatakan bahwa Allah adalah aktan pengirim-penerima; manusia sebagai pengujar adalah aktan penerima-pengirim. Dalam kebanyakan surat al-Quran, Allah adalah aktan penngirim (destinaire) pesan. Akan tetapi hal sebaluknya juga bisa berlaku: manusia menjadi "pengirim" dan Allah menjadi "penerima". Analisis aktansial ini tidak saja diterapkan pada tingkat sintaksis tapi juga terhadap seluruh teks sebagai suatu kesatuan atau seluruh narasi.

2) Suatu saat antropologi, mengenali dalam al-Quran bahasa yang bersusunan mitis.

Mitos adalah salah satu pengertian dasar paling berkembang yang direhabilitasi dan ditonjolkan oleh antropologi sosial dan budaya. Dewasa ini orang sepakat untuk menganggap mitos sebagai sebuah ungkapan simbolis kenyataan yang asli dan universal. Kisah mitos kurang lebih bergantung pada situasi sosial budaya tempat kisah tersebut diolah. Bagaimana pun halnya, mitos berfungsi untuk menghidupkan kembali masa kebersahajaan, suatu ruang mental di

${ }^{70}$ Cecep Ramli Bihar Anwar, Muhammad Arkoun: Cara Membaca Al-Qur'an, 11 of 15. 
mana berbagai tindakan manusiawi tidak hanya menjadi bermutu, tetapi juga bergairah. Definisi yang demikian itu menyajikan kegunaan yang amat luas untuk memungkinkan suatu interpretasi secara mendalam terhadap segala budaya yang dianggap mandiri dan berkiatan dengan (hidup) kita. Dengan mempertanyakan tipe mitologi apa yang membentuk al-Qur'an, maka kita memperluas peluangpeluang untuk memahami berbagai mekanisme yang sulit dicerna dari ungkapan simbolis al-Qur'an. ${ }^{71}$

Professor linguistik dari Swis, J. Starobinski, mengartikan hubungan kritis sebagai "a transcoding, a free transcription of varios data presented in the "interior" of the 'teks' ". Keberhasilan suatu kritik teks bukan terletak pada kemampuannya untuk mengupas. Keberhasilannya harus diarahkan pada hubungan-hubungan yang ada pada teks yang tidak lain adalah "the driving force behind the teks"

Asumsi Strobinski ini terutama berlaku bagi penafsiran teks-teks keagamaan. Arkoun telah berusaha melampaui keterbatasan linguistik tersebut. Dalam hal ini, Starobinski telah memberikan andil besar dalam usaha Arkoun untuk memberikan pertanggungjawaban metodologis. Arkoun meninggalkan aras kritis dan analitis menuju aras relasional. Pada aras ini, qiraat diarahbidikkan kepada singnifie dernier, petanda akhir. Dalam rangka mecari pertanda akhir inilah Arkoun beranjak pada tahap (moment) antropologis dimana ia memakai analisis mitis. Bila pada tahap linguistis-kritis data linguistis pertama-tama dianggap sebagai "kata sebagai tanda" (mot-signe), maka pada tahap antropologisn data linguistis kemudian dianggap sebagai "kata sebagai simbol $^{72,}$ (mot-syimbole). ${ }^{73}$

\footnotetext{
${ }^{71}$ Moh. Slamet Untung, "Pembacaan al-Quran" menurut Mohammed Arkoun, Jurna Religia Vol 13, No 1 ,(April 2015), 35.

${ }^{72}$ Untuk menghindari kebingungan dan kerancuan mengenai alur pemikiran Arkoun, disini perlu diuraikan secara singkat pengertian mengenai tanda (sign), simbol (syimbol) dan mitos (myith). Tanda adalah segala sesuatu yang menunjuk di luar dirinya. Lima huruf r, u, m, a, dan h adalah tanda yang bisa menunjuk (designare) sesuatu diluar dirinya, yaitu rumah dalam realitasnya. Simbol juga semacam tanda. Setiap simbol adalah tanda, tetapi tidak setiap tanda simbol. Sebab, simbol mempunyai ciri khas: rujukan ganda. Merah misalnya, tidak saja berarti merah buat darah, tetapi juga untuk simbol keberanian. Maka merah menjadi simbol karena memiliki rujukan ganda. Mitos adalah mirip simbol. Mitos adalah sejenis simbol yang diungkapkan dalam kisah atau cerita, yang terjadi dalam waktu dan tempat. Mitos adalah wahana orang untuk bisacerita tentang kehidupan eksistensial dirinya sendiri, masyarakat alam yang mendalam dan rumit. Karenanya struktur cerita mitis sangat kental dengan sublim. Lihat foot note Cecep Ramli Bihar Anwar, Op.Cit, 15 of 15.
} 
Penekanan kata-tanda kepada kata-lambang berarti memperkuat penekanan bahasa diskursif atau konkrit ke dalam bahasa mitis. Dengan demikian, tidak sulit menyatakan bahwa bahasa al-Qur'an: benar, karena berhasil-guna bagi kesadaran manusiawi yang tidak saja digiatkan oleh suatu bahasa mitis lain yang terbuka terhadap berbagai perspektif yang sepadan; berhasil-guna karena berkaitan dengan masa ciptaan primordial dan meresmikan secara mandiri suatu masa istimewa: masa Wahyu, masa kenabian Muhammad, dan salaf al-Salih; spontan, suatu pencaran keyakinan-keyakinan berkesinambungan yang tidak bersandar pada pembuktian (nalar); simbolis. ${ }^{74}$

Menurut Arkoun, semua ciri yang telah dikenal sebagai gaya mistis dalam Alkitab dan Perjanjian baruterdapat juga dalam al-Quran. Gaya bahasa al-Quran itu adalah: Pertama, benar. Karena gaya bahasa itu efektif mengenai kesadaran manusia yang belum digalakkan oleh gaya bahasa mitis lain yang membuka berbagai perspektif yang sebanding; Kedua, efektif. Karena gaya bahasa itu menghubungkan dengan waktu purba penciptaan dan karena gaya bahasa itu sendiri memulai suatu waktu yang istimewa: waktu pewahyuan, kenabian Muhammad dan para sahabat yang solih (as-salaf as-solih); Ketiga, sepontan. Kerena gaya bahasa itu merupakan pancaran terus menerus dari kepastian-kepastian yang tidak berdasarkan pada pembuktian, melainkan pada kesesuaian yang mendasar pada semangat-semangat yang permanen dalam kepekaan manusia; Keempat, simbolis. Bisa dilihat sebagai dari surga sebagai surga tuhan yang penuh dengan bidadari-bidadari yang merangsang birahi dan di situ mengalir sungai-sungai anggur dan madu.

3) Suatu saat historis yang di dalamnya akan ditetapkan jangkauan dan batas-batas tafsir logiko-legsikografis dan tafsir-tafsir imajinatif yang sampai hari ini dicoba oleh kaum muslim. ${ }^{75}$

Arkoun menyadari bahwa dengan kelahiran teks al-Quran, perubahan mendasar dikalangan umat dalam memahami wahyu telah terjadi. Raison graphique (nalar grafis) talah mendominasi cara berpikir umat sehingga logos kenabian (prophetique) didesak oleh logos

\footnotetext{
${ }^{73}$ Cecep Ramli Bihar Anwar, Muhammad Arkoun: Cara Membaca Al-Qur'an, 12 of 15. Arkoun, 35 .

${ }_{74}$ Moh. Slamet Untung, "Pembacaan al-Quran” menurut Mohammed

${ }^{75}$ Hermeneutika Muhamed Arkoun: Sekedar Pengantar, 12 of 12.
} 
pengajaran (professoral). Selain itu, terjadi pemiskinan kemungkinan untuk memahami wahyu dari segala dimensinya.

Dalam kategori semiotik, teks al-Quran sebagai parole ${ }^{76}$ didesak oleh teks sebagai langue ${ }^{77}$ sehingga al-Quran kini tetap menjadi parole bagi kaum mukmin. Untuk itulah menurut Arkoun, tujuan qira'at adalah comprendre, mengerti komunikasi kenabian yang hendak disampaikan lewat teks yang bersangkutan, yaitu mencari makna yang hendak disampaikan lewat taks tersebut dengan cara mengoptimalkan setiap kemungkinan untuk mereproduksi makna. Menurut Arkoun, ada tiga macam cara pembacaan al-Quran:

a) Secara liturgis,yaitu memperlakukan teks secara ritual yang dilakukan pada saat-saat shalat dan doa-doa tertentu. Pembacaan liturgis ini bertujuan "mereaktualisasikan saat awal ketika Nabi mengajarkannya untuk pertama kali" agar didapatkan kembali keadaan ujaran (situation de discour) dari ujaran l. Dengan cara ini manusia melakukan komunikasi rohani, baik secara horizontal maupun vertical, dan sekaligus melakukan pembatinan terhadap kandungan wahyu.

b) Pembacaan secara eksegesis yang berfokus pada "ujaran 2", yaitu ujaran yang termaktub di dalam mushaf, seperti yang dilakukan oleh Fakhr Ad-Din Ar-Razi. (w. 606 H/1209 M).

c) Cara baca yang ingin dikenalkan oleh Arkoun, yaitu dengan memanfaatkan temuan-temuan metodologis yang disumbangkan oleh ilmu-ilmu kemanusiaan dan ilmu bahasa.

Menurut Arkoun, ketiga cara baca tersebut tidak saling menyisihkan antara satu sama lain. Bahkan saling memberikan sumbangan untuk memahami teks-teks Ilahi yang tidak akan pernah tuntas dibahas oleh manusia. ${ }^{78}$

Untuk pembacaan seperti itu, Arkoun mengajukan tahap pembacaan al-Quran ke dalam dua tahap kritis, yaitu tahap linguistik kritis dan tahap hubungan kritis. Dalam tahap pertama, pembaca

${ }^{76}$ Parole adalah keseluruhan yang diujarkan orang dan merupakan manifestasi individu dari bahasa. (lihat: Moh. Fauzan Januri dan Muhammad Alfan, Dialog Pemikiran Timur Barat, 228)

${ }^{77}$ Langue adalah keseluruhan kebiasaan yang diperoleh secara pasif yang diajarkan oleh masyarakat bahasa. (lihat: Moh. Fauzan Januri dan Muhammad Alfan, Dialog Pemikiran Timur Barat, 228)

${ }^{78}$ Moh. Fauzan Januri dan Muhammad Alfan, Dialog Pemikiran

Timur Barat, 227-228. 
dilakukan dengan memakai data-data lingustik (seperti tanda-tanda bahasa, modalisateurs du discours, aras sintaksis, aras semantic dan sebagainya) untuk mengetahui maksud dari pengujar (locateurs). Pada tahap kedua,pembacaan dilakukan dengan menempuh dua langkah. Pertama, eksplorasi historis (memiliki khazanah tafsir klasik dan berupaya menemukan petanda terakhir di dalamnya dengan kode-kode linguistik, keagamaan cultural, simbolis, anagosis dan sebagainya) kedua, eksplorasi antropologis (dilakukan dengan analisis mitis/simbolis, dengan memeriksa tanda, symbol dan mitos yang menyerupai sebuah qira'ah). ${ }^{79}$

Adapun tujuan membaca al-Quran (qira;at) bagi Arkoun adalah untuk mengerti (comprendre) komunikasi kenabian yang disampaikan lewat teks tertulis. Dengan kata lain, qira'at dilakukan untuk melakukan semacam "napak tilas" proses pengujaran (enonciation) alQuran dari berbagai segi dan dimensinya, sebagaimana waktu pertama kali diungkapkan dalam suasana semiologis yang masih kaya dan segar. Artinya tujuan qira'at bukan semata-mata untuk mengerti teks, melainkan untuk mendapatkan teks. secara metodologis, "napak tilas" ini sebennarnya tidak mungkin karena proses pengujaran hanya terjadi satu kali, unik dan karenanya tak akan pernah terulang lagi. Yang paling mungkin dilakukan hanyalah menjulurkan tangan secara asimtosis $^{80}$ kepada suatu pendekatan yang makin lama makin akrab dengan wacana itu, dengan cara mengembalikan (dengan segala keterbatasanya) teks al-Quran sebagai lengue menjadi parole bagi orangorang yang hidup pada zaman sekarang ini.

Bagi Arkoun, qira'at juga dimaksudkan untuk untuk memproduksi makna-makna yang berada di balik teks harfiah dengan cara mangungkap struktur bahasa mitis al-Quran dan melepaskannya dari jebakan bahasa logis dan logosentris. Tampaknya bagi Arkoun qira'at juga berarti manangkap pesan universal dan asas paling primordial yang berada di balik semua al-Kitab (seluruh kitab suci yang diturunkan Allah kepada umat manusia lewat perantaraan para Rasul-Nya), dengan melakukan semacam ziarah sipiritual vertikal

\footnotetext{
${ }^{79}$ Moh. Fauzan Januri dan Muhammad Alfan, Dialog Pemikiran Timur Barat 229.

${ }^{80}$ Asimptotis (asyimtotique) adalah semakin mendekati, tetapi tidak pernah mencapai seluruhnya. Istilah ini diambil dari kosa kata matematika. (lihat: Cecep Ramli Bihar Anwar, Muhammad Arkoun: Cara Membaca Al-Qur'an, Islamlib.com, foot note ke 33).
} 
melalui gerk-balik menaiki tangga gerakan linear tanzil al-Quran yang dikemukakannya, sampai pada sabda ataukalam Allah yang tak terhingga, guna mendamaikan perang teologis yang terjadi diantara masyarakat kitab. Karena itu, Arkoun menginginkan tafsirnya mampu mengatasi masalah ketegangan klaim teologis ini: "Keinginan kami adalah membuat mungkin suatu penanganan yang solider terhadap kitab-kitab suci oleh orang "ahlu kitab" ${ }^{81}$ untuk itu kami mengajak pembaca untuk membaca al-Quran menurut aturan-aturan suatu metode yang dapat diterapkan kepada semua teks doktrinal besar. ${ }^{82}$

\section{b. Penafsiran Al-Quran menurut Arkoun}

Studi Muhammad Arkoun atas teks al-Qur'an adalah untuk mencari makna lain yang tersembunyi di sana. Maka, untuk menuju rekontruksi (konteks), harus ada dekontruksi (teks). Arkoun termasuk intelektual muslim yang sangat berani dalam menafsirkan alQur'an bukan dari tradisi Islam tapi denga metodologi impor dari budaya barat.

\section{1) Historis-Antropologis}

Dalam buku Mohammed Arkoun yang diterjemahkan ke dalam bahasa Arab menjadi Tarikhiyah al-Fikr al-Arabi al-Islami (Histirisisme pemikiran Arab-Islam). Arkoun bermaksud hendak melihat seluruh fenomena sosial-budaya lewat perspektif historis, bahwa masa lalu harus dilihat menurut strata historikalnya. Mencari historis harus dibatasi menurut runtutan kronologis dan fakta-fakta nyata. Ini artinya, historisisme berperan sebagai metode rekontruksi makna lewat penghapusan relevansi antara teks dengan konteks. Jika metode ini diaplikasikan ke atas teks-teks agama, apa yang

${ }^{81}$ Ahli kitab adalah orang-orang Yahudi dan Kristen yang harus dihadapi Muhammad di Mekkah dan Medinah. Mereka disebut dalam Quran sebagai pemilik wahyu yang lebih awal, orang-orang beriman yang dikasihi Allah sama dengan orangorang Muslim, yang telah menerima wahyu yang baru. Ibrahim bukan Yahudi atau Kristen, melainkan "Muslim" murni, seorang beriman yang sepenuhnya mengabdi Allah. Perspektif sejarah spiritual ini atau sejarah penyelamatan sangat jelas dalam alQuran dan merupakan dimensi penting teologi modern tentang wahyu. Sajian lain tentang ahl al-kitab dalam al-Quran menyebutkan orang-orang Yahudi dan Kristen menentang Muhammad dan pernyataan bahwa ia seorang nabi, dan mereka menolak Quran sebagai Wahyu Firman Allah yang terakhir. Lihat: Mohammed Arkoun, Gagasan tentang Wahyu: dari Ahl al-Kitab sampai Masyarakat Kitab, di dalam Studi Islam Prancis bawah redaksi H. Chambert-Loir dan N.J.G. Kaptein, (Jakarta:INIS, 1993), 53.

${ }^{82}$ Cecep Ramli Bihar Anwar, Muhammad Arkoun: Cara Membaca Al-Qur'an, Op.Cit, 10 of 15. 
dibutuhkan, menurut Arkoun, adalah makna-makna baru yang secara potensial bersemayam dalam teks-teks tersebut. ${ }^{83}$

Bagaimana Arkoun melihat tradisi atau turats? Secara umum, Arkoun membedakan antara dua bentuk tradisi. Dalam karya-karya yang ditulisnya dalam bahasa Perancis, ia secara bersamaan menggunakan dua kata "tradition"dan turats, dan membagi keduanya kepada dua jenis: pertama, Tradisi atau Turats dengan $\mathrm{T}$ besar, yaitu tradisi yang transenden yang selalu dipahami dan dipersepsikan sebagai tradisi ideal, yang datang dari Tuhan dan tidak dapat diubahubah oleh kejadian historis. Tradisi semacam adalah abadi dan absolute. Sedangkan tradisi Jenis kedua ditulis dengan $\mathrm{T}$ kecil (tradition/turats). Tradisi ini dibentuk oelh sejarah dan budaya manusia, baik yang merupakan warisan turun temurun sepanjang sejarah kehidupan, atau penafsiran manusia atas wahyu Tuhan lewat teks-teks kitab suci. Antara dua jenis traidis ini, Arkoun mengesampingkan jenis yang pertama, karena menurutnya, traidsi tersebut berada di luar pengetahuan dan kapasitas akal manusia. Dengan begitu, target dan objek kajian yang akan dilakukannya adalah turats jenis yang kedua; turats yang dibentuk oleh kondisi sejarah (kondisi ruang-waktu). ${ }^{84}$

Membaca turats adalah membaca teks, semua jenis teks. Karena dibentuk dan dibakukan dalam sejarah, turats tersebut harus dibaca melalui kerangka sejarah. Baginya, salah satu tujuan membaca teks, khususnya teks suci, adalah untuk menghargainya di tengah perubahan yang terus terjadi. Artinya, berbagai ajaran agama yang berasal dari teks suci harus selalu sesuai dan tidak bertentangan dengan segala keadaan. ${ }^{85}$ Dengan kata lain ajaran-ajaran agama yang berasal dari teks suci tersebut harus selalu sesuai dan tidak bertentangan dengan segala keadaan, inilah salah satu inti pesan ajaran Islam itu; al-Islam yashluh li kulli zaman wa makan. Dari sini apa yang sedang diusahakan Arkoun, sepertinya ingin memaksakan al-Quran mengikuti perkembangan zaman bukan al-Quran dijadikan petunjuk sepanjang zaman. ${ }^{86}$

\footnotetext{
${ }^{83}$ Badrus Syamsi, Metodologi Studial-Quran Muhammad Arkoun: Kajian Kritis, Op.Cit, 5 of 12.

${ }^{84}$ Badrus Syamsi, Metodologi Studial-Quran Muhammad Arkoun: Kajian Kritis, 5 of 12.

${ }^{85}$ Siti Rohmah Soekarba, kritik Pemikiran Arab: Metode Dekonstruksi Mohammed Arkoun, Wacana, VOL 8, NO l, APRIL 2006, 83.

${ }^{86}$ Badrus Syamsi, Metodologi Studial-Quran Muhammad
} 


\section{2) Penafsiran Linguistik-Semiotika}

Mohammed Arkoun dalam teori semiotikanya terpengaruh atau lebih tepaatnya mengadopsi teori Ferdinand de Daussure (1857-1913), seorang tokoh semiotika Prancis, menurut De Daussure fenomena bahasa secara umum ditunjukkan dengan istilah langange. Dalam bahasa langange terdapat dikotomi antara parole dan langue. Parole adalah bagian dari bahasa yang sepenuhnya individual. Satu hal yang menjadi karakteristik dari parole adalah adanya keunikan bahasa dari tiap pribadi. Sedangkan langue adalah suatu sistem kode yang diketahui oleh semua anggota masyarakat pemakai bahasa tersebut, dan seolah-olan kode-kode itu telah disepakati bersama di masa lalu di antara pemakai bahasa tersebut. Langue merupakan suatu sistem sosial dan sekaligus sistem nilai. Sebagai sistem sosial langue tidak di rencanakan sendiri. Itulah sisi sosial dari langange. Secara implisit dapat ditangkap bahwa langue dan parole beroposisi, tetapi sekaligus juga saling tergantung. Di satu sisi, sistem yang berlaku dalam langue adalah hasil produksi dari kegiatan parole, sementara di sisi lain, pengungkapan parole serta pemahamannya hanya mungkin apabila didasarkan pada penelusuran langue sebagai sistem. ${ }^{87}$

Sebagaimana ahli-ahli linguistik yang menyelidiki bahasa dengan hanya membatasi diri pada wilayah langue saja, Arkoun menganggap bahwa al-Quran yang bisa disentuholeh manusia sebenarnya hanya sisi langue dari wahyu Tuhan. Karena sifatnya yang terbatas dan transenden, manusia tidak mungkin mampu menyentuh parole Tuhan. ${ }^{88}$

Oleh karena itu, pengaruh semiotikanya Ferdinand de Daussure ini dibawa oleh Arkoun dengan mengklasifikasikan tingkatan-tingkatan pemaknaan atas wahyu, untuk mengetahui posisi al-Quran yang kita pegan sekarang ini. Arkoun menyebutkan ada tiga tingkatan pemaknaan wahyu: pertama, wahyu sebagai parole (firman,sabda, kalam) Allah yang transenden, tak terbatas (infinite). Untuk menunjuk realitas semacam ini biasanya al-quran menggunakan terma al-lauh al-mahfudz

\footnotetext{
Arkoun: Kajian Kritis, 5 of 12.

${ }^{87}$ Badrus Syamsi, Metodologi Studi al-Quran Muhammad Arkoun: Kajian Kritis, 6 of 12.

${ }^{88}$ Badrus Syamsi, Metodologi Studial-Quran Muhammad Arkoun: Kajian Kritis, 6 of 12.
} 
(the well preserved table) atau umm al-Kikab (the Archetype Book). Tingkat kedua, wahyu dalam sejarah. Berkenaan dengan al-Quran, konsep wahyu tingkat kedua ini menunjuk pada realitas firman Allah sebagaimana diwahyukan dalam bahasa Arab kepada Muhammad lebih dari dua puluh tahun. Jika pada tingkat pertama wahyu mengacu pada parole Tuhan maka tingkat kedua ini bisa dikatakan mengacu pada langue dari al-Quran. Tapi penting dicatat bahwa pada tingkat kedua ini al-Quran masih berbentuk oral, lisan. Tingkat ketiga, menunjuk wahyu dalam bentuk korpus resmi tertutup atau wahyu yang sudah ditulis dalam mushaf dengan huruf dan berbagai tanda baca yang ada di dalamnya.. pengertian ini menunjuk pada mushaf Utsmani, yang pada tahun 1924 diterbitkan edisi standar al-Quran di Kairo, Mesir. Wahyu pada tingkat ketiga ini merupakan rekaman dari langue Tuhan yang menyejarah pada tingkat kedua dan pada saat yang sama, dalam beberapa hal, telah meredukasi kekayaan sifat oral yang dimilikinya. Semenara itu, terma al-Quran sendiri dalam bahasa Arab mengacu secara bersamaan ke seluruh tingkatan di atas. Oleh karena iitu, Suhaidi dalam bukunya Kawin Lintas Agama, menyatakan bahwa tingkatan wahyu seperti ini pernah ada dalam tradisi Islam, yakni teori wahyu Mu'tazilah yang menyatakan bahwa "wahyu Tuhan diciptakan". Namun pernyataan ini ditolak oleh ortodoksi (Asy'ariyyah) dengan teori wahyu itu qadim. ${ }^{89}$

Dalam semiotika (ilmu tentang tanda (sign) atau ilmu yang mempelajari perkembangan sign dalam masyarakat), Arkoun berusaha menunjukkan fakta sejarah tentang bahasa al-Quran pada dasarnya mempunyai dua tujuan: yang pertama, untuk menampakkan fakta sejarah dari bahasa al-Quran; yang kedua, untuk menunjukkan bagaimana arti baru dapat diperoleh dari teks al-Quran tanpa dibatasi oleh cara kajian tradisional. ${ }^{90}$

\section{3) Penafsiran Teologis- Religius}

Menurut Arkoun, jika seseorang terus menganggap Al-Qur'an sebagai sebuah teks dari Tuhan secara transcendental, orang akan hanya berakhir pada masalah-masalah yang lebih bersifat teologis. Kemudian, satu jenis theology yang diperlukan disini, katanya, adalah 'sebuah keyakinan yang rasional' yang didasarkan kepada konfrontasi

\footnotetext{
${ }^{89}$ Badrus Syamsi, Metodologi Studi al-Quran Muhammad Arkoun: Kajian Kritis, 6 of 12.

${ }^{90}$ Badrus Syamsi, Metodologi Studi al-Quran Muhammad Arkoun: Kajian Kritis, 7 of 12.
} 
antara episteme yang ada pada titik tertentu dengan masalah-masalah yang ditimbulkan oleh teks keagamaan, yakni, antara warisan dan sejarah.

Arkoun menolak keyakinan secara umum bahwa 'Islam tidak memisahkan spiritual dengan duniawi', dia meyakinkan para pembacanya bahwa sekularisme berakar dalam Islam. Sebagaimana Harvey cox telah membuat justifikasi sekularisasi dari bible, Arkoun juga mengatakan,"sekularisme sudah ada dalam Al-Qur'an dan piagam Madinah." Ini bukan kesimpulan yang berdasarkan fakta sejarah, namun sebuah ide yang mengikuti ide sebelumnya. Arkoun benarbenar mendeklarasikan tujuan utamanya dalam sebuah essai "Islam and Secularism" dimana dia menyataka, "kita perlu mendekontruksi kaum ortodoks tertutup dari dalam. Ini tidak mungkin dilakukan kecuali mencari sebuah sejarah yang bebas yang dapat mengarahkan masuknya ide sekulerasi dalam Islam." Sekularisme kemudian merupakan sebuah dogma yang sudah terbentuk sebelumnya yang perlu di promosikan dan diperkuat dengan segala usaha, bahkan jika perlu fakta-fakta sejarah dapat diputarbalikkan untuk kepentingan ini. Jika Arkoun berhasil menghindari sebuah tafsir yang berorientasi pada keyakinan untuk menggelakkan 'dogma-dogma' Sunni atau Shi'ah, nyatalah dia telah menjatuhkan mangsanya kedalam sebuah teologi sekuler dengan dogma-dogmanya sendiri. ${ }^{91}$

Salah satu ciri khas sekuler adalah tidak memberikan tempat kepada Tuhan dalam sejarah kehidupan manusia, begitu juga Arkoun, dia berpendapat bahwa dalam sejarah manusia Tuhan tidak terlibat. Sebagaimana dia memahami al-Qur'an, dia mengatakan Mushaf Ustmani ini menunjukkan beberapa fakta sejarah yang tergantung keadaan sosial dan politik, bukan tergantung kepada Tuhan. ${ }^{92}$

\section{G. Karya-Karya Arkoun}

Mohammad Arkoun tergolong seorang ilmuan yang sangat produktif.ia telah menulis banyak buku penting belasan bukunya ditulis dalam bahasa Prancis dan sebagian ditulis dalam bahasa Inggris. Walaupun Arkoun termasuk ahli dalam bahasa Arab, karena disamping ia telah mempelajarinya sajak masih muda juga bertahuntahun ia mendalami khazanah kesusastraan Arab klasik, namun, Arkoun belum pernah dalam bahasa Arab dengan versi aslinya.

\footnotetext{
${ }^{91}$ Badrus Syamsi, Metodologi Studial-Quran Muhammad Arkoun: Kajian Kritis, 7 of 12.

${ }_{92}$ Badrus Syamsi, Metodologi Studi al-2uran Muhammad Arkoun: Kajian Kritis, 8 of 12.
} 
Beberapa karyanya dalam bahasa Arab merupakan terjemahan dengan penerjemah orang Arab. ${ }^{93}$

Beberapa karya Arkoun yang penting adalah:

1. Traite d'ethique (tradition francaise avec introduction et notes du Tahdhib AlAkhlaq) (sebuah pengantar dan catatan-catatan tentang etika dan Tahzib Al-Akhlaq Miskawaih);

2. Contribution a l'etude de l'humanisme arabe au IVe/Xe siècle: Miskawayh philosophe et histirien (sumbangan terhadap pembahasan humanisme Arab abad ke-4 H/10 M Miskawaih sebagai filsuf dan sejarawan).

3. La pensee arabe (pemikiran Arab).

4. Ouvertures sur l'islam (catatan-catatan pengantar untuk memahami Islam).

Buku-buku Arkoun yang merupakan kumpulan artikel di beberapa jurnal antara lain adalah Essais sur la pensee Islamique (Esai-esai tentang pemikiran Islam) Lectures du Coran (Pembacaan-pembacaan alQuran) dan Pour une critique de la raison Islamique (Demi kritik nalar Islam). Buku-bukunya yang lain adalah Aspects de la pense musulmane calssique (Aspek-aspek pemikiran klasik), Deux Epitres de miskawayh (Dua surat Miskawayh), Discours coranique et penseescientifique (Wacana alQuran dan pemikiran ilmiah), L'Islam, hier, demain (Islam, kemarin dan esok, karya bersama Lois Garded), dan L'Islam, religion et societe (Islam, agama dan masyarakat), ${ }^{94}$ dan masih banyak lagi buku-buku atau pun artikel karya Akoun yang lainnya.

Karya-karya Arkoun tersebut kalau dicermati ternyata banyak diilhami oleh para ilmuan Prancis, seperti Paul Ricoeur, Michel Fouchault, Jack Derrida, Roland Barthes dan Piere Bourdieu. Di samping itu diilhami ahli bahasa Swiss, Ferdinand de Saussure, antropologi Inggris, Jack Goody, ahli sastra Kanada , Nordthrop Frye, dan sebagainya.

Arkoun terus mencoba pengalaman-pengalaman baru tentang Islam dan kaum muslim dengan menggunakan teori-teori mutakhir yang berkembang di dunia Barat modern. Upaya tersebut dilakukan Arkoun untuk memadukan unsure yang sangat mulia dalam pemikiran Islam dengan unsur yang sangat berharga di dalam pemikiran Barat

\footnotetext{
${ }^{93}$ Baedhowi, Humanisme Islam, 39.

${ }^{94}$ Moh. Fauzan Januri dan Muhammad Alfan, Dialog Pemikiran Timur Barat 217.

${ }^{95}$ Moh. Fauzan Januri dan Muhammad Alfan, Dialog Pemikiran Timur Barat 218.
} 
modern (rasionalitas dan sikap kritis). Dengan begitu, Arkoun berharap akan muncul suatu pemikiran yang bisa memberikan jawaban atas berbagai persoalan yang dihadapi oleh kaum muslim akhir-akhir ini dan dapat membebaskannya dari belenggu yang mereka ciptakan sendiri. ${ }^{96}$

\section{H. Kesimpulan}

Mohammed Arkoun lahir pada tanggal l Februari 1928 dalam keluarga biasa di perkampungan Barber yang berada di kaki gunung Taorirt-Mimoun, Kabilia sebelah timur Aljir, Aljazair. Dari keluarga yang berada dalam strata fisik dan sosial yang rendah membuat dirinya terpacu untuk memperbaiki kahidupannya dari segi pendidikan hingga menghabiskan sebagian waktunya untuk berkarir di negara Perancis. Dengan menguasai tiga bahasa (Kabilia Barber sebagai bahasa ibu, bahasa Arab sebagai bahasa nasional Aljazair, dan bahasa Perancis), sesungguhnya mewakili tiga tradisi, orientasi budaya, cara berpikir dan cara memahami yang berbeda.

Sebagai seorang intelektual yang hidup di dua dunia, timur dan barat, Pemikiran dan karya-karya Arkoun sangat ketara dipegaruhi oleh gerakan (post) strukturalitis Perancis. Metode historisme yang dipakai Arkoun adalah formulasi ilmu-ilmu sosial barat modern hasil ciptaan para pemikir (post) strukturalis Perancis_referensi utamanya adalah De Sausure (linguistik), Levi Staurus (antropologi), Lacan (psokologi), Barthes (smiologi), Foucault (epistimologi), Derrida (grammatologi) filosof Perancis Paul Ricour, antropolog seperti Jack Goody dan Pierre Bourdieu. Arkoun memanfaatkan keilmuan Barat Modern khususnya Perancis dengan memanfaatkan segala keilmuan mutakhir (ilmu-ilmu sosial dan ilmu bahasa) seperti ilmu sosiologi, antropologi, linguistik untuk pemikiran Islam.

\section{Daftar Pustaka}

${ }^{96}$ Moh. Fauzan Januri dan Muhammad Alfan, Dialog Pemikiran 
Anwar, Cecep Ramli Bihar. Muhammad Arkoun: Cara Membaca Al-Qur'an. Islamlib.com. 09 Juli 2002.

Arkoun, Mohammed. 1993. Gagasan tentang Wahyu: dari Ahl al-Kitab sampai Masyarakat Kitab. di dalam Studi Islam Prancis bawah redaksi H. Chambert-Loir dan N.J.G. Kaptein.Jakarta:INIS.

Baedhowi. 2008. Humanisme Islam: Kajian Terhadap Pemikiran Filosofis Muhammad Arkoun. Yogyakarta: Pustaka Pelajar

Esposito, John. L. t.t. Ensiklopedi Oxford Dunia Islam Modern. T.tp.: Meizan.

Fauzan, Moh. dan Muhammad Alfan. 201l. Dialog Pemikiran Timur Barat. Bandung: Pustaka Setia.

Hasib, Kholili. Mohammed Arkoun dan Desakralisasi Al-Qur'an. Inpasonline.com. Diakses selasa, 21 September 2010

Hidayati, Nuril. Modernitas dalam Pemikiran Islam Mohammad Arkoun. online diakses pada 1 Desember 2017.

Latif, Muhaemin. 2013. Membumikan Teeologi Islam dalam Kehidupan Modern (Berkaca dari Mohammed Arkoun), Jurnal Dakwah Tabligh. Vol 14. No 2.

Lee, Robert D. t.t. Mecari Islam Autentik: dari Nalar Puitis Ikbal hingga Nalar Kritis Arkoun. T.tp.: Mizan.

Marpaung, Irwan Malik. Kritik terhadap 'Kritik Nalar Islam' Arkoun. Inpasonline.com.

Muchtar, M. Ilham. 2016. Analisis Konsep Hermeneutika dalam Tafsir al-Quran Hunafa: Jurnal Studia Islamika. Vol 13. No 1.

Munir, Ahmad. "Kritik Nalar Islam: Analisis atas Pemikiran Muhammad Arkaoun". 2008 Al-Tahrir Jurnal Pemikiran Islam Vol 8.

Nasrudin. 2016. Manhaj Tafsir Muhammad Arkoun, Jurnal Maghza Vol 1. No 1 . 
Soekarba, Siti Rohmah. 2006. Kritik Pemikiran Arab: Metode Dekonstruksi Mohammen Arkoun. Jurnal Wacana. Vol 8. No 1.

Syamsi, Badrus. Metodologi Studi al-Quran Muhammad Arkoun: Kajian Kritis. Inpasonline.com. Diakses Selasa 21 September 2010.

Untung, Moh. Slamet. 2015 "Pembacaan al-Quran" menurut Mohammed Arkoun. Jurna Religia Vol 13. No 1.

Widayati, Ratna. 2012. Muhammed Arkuon; Biografi dan Pemikiran. Artikel Diakses pada 1 Desember dari https://afidburhanuddin.files.wordpress.com.

2009. Hermeneutika Muhamed Arkoun: Sekedar Pengantar. T.tp.:T.pn.

2010. Arkoun,Telah Tiada dan Telaah Kritis Pemikirannya. Inpasonline.

2010. Arkoun, telah Tiada dan Telaan Kritis Pemikirannya. Inpasonline. 20/09/10.

https://id.m.wikipedia.org.

Langgulung, Hasan. "Islamisasi pendidikan dari perspektif metodologi." Jurnal Pendidikan Islam 9.3 (2001): 17-32. 
